\title{
Lattice-preferred orientations of late-Variscan granitoids derived from neutron diffraction data: implications for magma emplacement mechanisms
}

\author{
Axel Müller • Bernd Leiss • \\ Klaus Ullemeyer $\cdot$ Karel Breiter
}

Received: 6 October 2009/Accepted: 6 August 2010 / Published online: 1 September 2010

(C) Springer-Verlag 2010

\begin{abstract}
The lattice-preferred orientation (LPOs) of two late-Variscan granitoids, the Meissen monzonite and the Podlesí dyke granite, were determined from high-resolution time-of-flight neutron diffraction patterns gained at the diffractometer SKAT in Dubna, Russia. The results demonstrate that the method is suitable for the LPO analysis of polyphase, relatively coarse-grained $(0.1-6 \mathrm{~mm})$ rocks. The Meissen monzonite has a prominent shape-preferred orientation (SPO) of the non-equidimensional minerals feldspar, mica and amphibole, whereas SPO of the Podlesí granite is unapparent at the hand-specimen scale. The neutron diffraction data revealed distinct LPOs in both granitoids. The LPO of the non-equidimensional minerals feldspar, mica and amphibole developed mainly during magmatic flow. In the case of the Meissen monzonite, the magmatic flow was superimposed by regional shear tectonics, which, however, had no significant effect on the
\end{abstract}

\footnotetext{
A. Müller $(\bowtie)$

Geological Survey of Norway,

Postboks 6315 Sluppen, Trondheim 7491, Norway

e-mail: Axel.Muller@ngu.no

B. Leiss

Geowissenschaftliches Zentrum Göttingen, Goldschmidtstr. 3, 37077 Göttingen, Germany

e-mail: bleiss1@gwdg.de

\section{K. Ullemeyer}

Institut für Geowissenschaften, Universität Kiel, Otto-Hahn-Platz 1, 24118 Kiel, Germany

e-mail: kullemeyer@ifm-geomar.de

\section{K. Breiter}

Institute of Geology, v.v.i.,

Academy of Sciences of the Czech Republic,

Rozvojová 269, 16500 Praha 6, Czech Republic

e-mail: breiter@gli.cas.cz
}

LPOs. In both samples, quartz shows a weak but distinct LPO, which is atypical for plastic deformation and different in the syn-kinematic Meissen monzonite and the postkinematic Podlesí granite. We suggest that, first of all, the quartz LPO of the Meissen monzonite is the result of oriented growth in an anisotropic stress field. The quartz LPO of the Podlesí granite, which more or less resembles a deformational LPO in the flattening field of the local strain field, developed during magmatic flow, whereby the rhombohedral faces of the quartz crystals adhered to the (010) faces of aligned albite and to the (001) faces of zinnwaldite. Due to shape anisotropy of their attachments, the quartz crystals were passively aligned by magmatic flow. Thus, magmatic flow and oriented crystal growth are the major LPO-forming processes in both granitoids. For the Meissen monzonite, the solid-state flow was too weak to cause significant crystallographic re-orientation of the minerals aligned by magmatic flow. Finally, the significance of our results for the evaluation of the regional tectonic environment during magma emplacement is discussed. The discussion on the regional implications of the more methodologically oriented results provides the basis for future, more regionally aimed studies in view of the fabric characteristics of such plutons and their developing mechanisms.

Keywords Neutron diffraction - Lattice-preferred orientation - Shape-preferred orientation - Magmatic flow . Podlesí granite $\cdot$ Meissen Massif

\section{Introduction}

Preferentially oriented minerals are a ubiquitous feature of granitic plutons (e.g. Bouchez 1997). However, parameters 
controlling type and intensity of the preferred orientations in granitic rocks are manifold, and discussion about their significance is still controversial (Paterson et al. 1989, 1998; Schulmann et al. 1997; Vernon 2000; Sen and Mamtani 2006; Žák et al. 2008). Two main categories of mineral-preferred orientations are recognised: shapepreferred orientation (SPO) and lattice-preferred orientation (LPO; e.g. Shelley 1993). SPO describes the anisotropic spatial arrangement of the long and/or short axis of elongated, oblate, platy or flaky ('non-equidimensional') minerals. LPO describes the anisotropic spatial arrangement of the crystal lattices in a population of mineral grains. Some mineral-preferred orientations consist either of a LPO or a SPO; others contain both these elements. SPOs of non-equidimensional mineral grains such as feldspar phenocrysts and mica flakes are fairly obvious at the handspecimen scale or in thin sections and define magmatic foliations. LPOs are less obvious; hence, optical universal stage (U-stage) and diffraction measurements or indirect methods such as anisotropy of magnetic susceptibility (AMS) measurements have to be applied to quantify the characteristics of the preferred orientation.

LPOs and SPOs of granitic rocks can be caused by magmatic flow, solid-state flow, oriented crystal growth and combinations of these processes (e.g. Blumenfeld and Bouchez 1988). Vernon (2000) defined end-member criteria, which are evident for magmatic flow and solid-state flow, respectively. Magmatic flow causes alignment of non-equidimensional mineral grains in granite melts by means of passive grain rotation. Solid-state flow in synkinematic granites causes crystallographic alignment of the mineral grains due to intracrystalline slip, rotation recrystallisation and sub-grain formation. Fabrics reflecting transitional conditions between magmatic and solid-state flow are difficult to distinguish from the rock fabric, e.g., because of strain partitioning into interstitial melt (Paterson et al. 1998). Hence, careful distinction and characterisation of flow-induced fabrics in magmatic rocks are essential for understanding the timing, architecture, deformation mechanisms and tectonic constraints of pluton emplacement. Another process causing LPO and/or SPO is oriented crystal growth during magma solidification after magma emplacement. The unidirectional solidification fabric is a typical example of macroscopically visible LPO resulting from oriented crystal growth (e.g. Shannon et al. 1982; Kirwin 2005). The term 'unidirectional solidification fabric' refers to multiple, sub-parallel layers of mm- to $\mathrm{dm}$-scale comb crystals oriented perpendicular to the layers (e.g. Shannon et al. 1982). In granitoid rocks, the comb crystals are usually parallel or sub-parallel to a nearby intrusion-wallrock or sub-intrusion-intrusion contact (e.g. Kirwin 2005).
Sander (1929) introduced the statistical analysis of quartz $c$-axes orientations in syn-kinematically emplaced granites using the U-stage. Sander's and most of the later studies of quartz orientation in plutons are from orogenic settings, in which the host rocks underwent regional deformation contemporaneously with magma emplacement. The LPO of quartz in these syn-kinematic granites may be explained by magmatic flow superimposed by solid-state flow during the final stage of magma solidification and/or post-crystallisation deformation (e.g. Phillips 1965; Hobbs et al. 1976; Vernon 1976; Gapais and Barbarin 1986; Paterson et al. 1989; Vernon 2000 and references therein). In most of these examples, it remains unclear whether the LPO of quartz records magma flow (intraplutonic magma dynamics) or contemporaneous regional tectonics or both. Maroscheck (1933), Watznauer and Behr (1966), Behr (1967, 1968), Mierzejewski (1968) and others demonstrated the presence of quartz LPOs in late-Variscan post-kinematic granites in the Bohemian Massif. However, they could not adequately explain the mechanisms of LPO formation.

The first petrofabric analyses on quartz applying time-offlight (TOF) neutrons were carried out by Bankwitz et al. (1985) and Damm et al. (1990). In this study, analyses of the LPOs of all rock-forming minerals in two granitic rocks were performed at the SKAT-diffractometer at the pulsed reactor IBR-2 in Dubna, Russia (Ullemeyer et al. 1998). The two granitoids are the Meissen monzonite of the Elbe Zone at the NE border of the Eastern Erzgebirge in Germany and the Podlesí dyke granite of the Western Krušne Hory (Western Erzgebirge) in Czech Republic. The Erzgebirge and the Elbe Zone are located at the northern margin of the Bohemian Massif and form parts of the Saxothuringian Zone of the Variscan orogeny. The Meissen monzonite synkinematically intruded the Elbe Zone at $334 \pm 3 \mathrm{Ma}$ (Hofmann et al. 2009), whereas the Podlesí dyke granite was emplaced during a quite passive post-orogenic tectonic event at $311 \pm 1 \mathrm{Ma}$ (Breiter et al. 2005; Fig. 1).

The aims of the study were as follows:

- To test the applicability of neutron diffraction method for LPO analysis of medium- to coarse-grained and polyphase rocks with low-symmetrical minerals, such as granitoids.

- To examine the effect of magmatic flow, oriented crystal growth and solid-state flow on the LPO formation in granitoids.

- To utilise LPO analyses for the better understanding of crystallisation and fabric development during magma emplacement.

- To discuss implications for the regional tectonic environment during magma emplacement. 

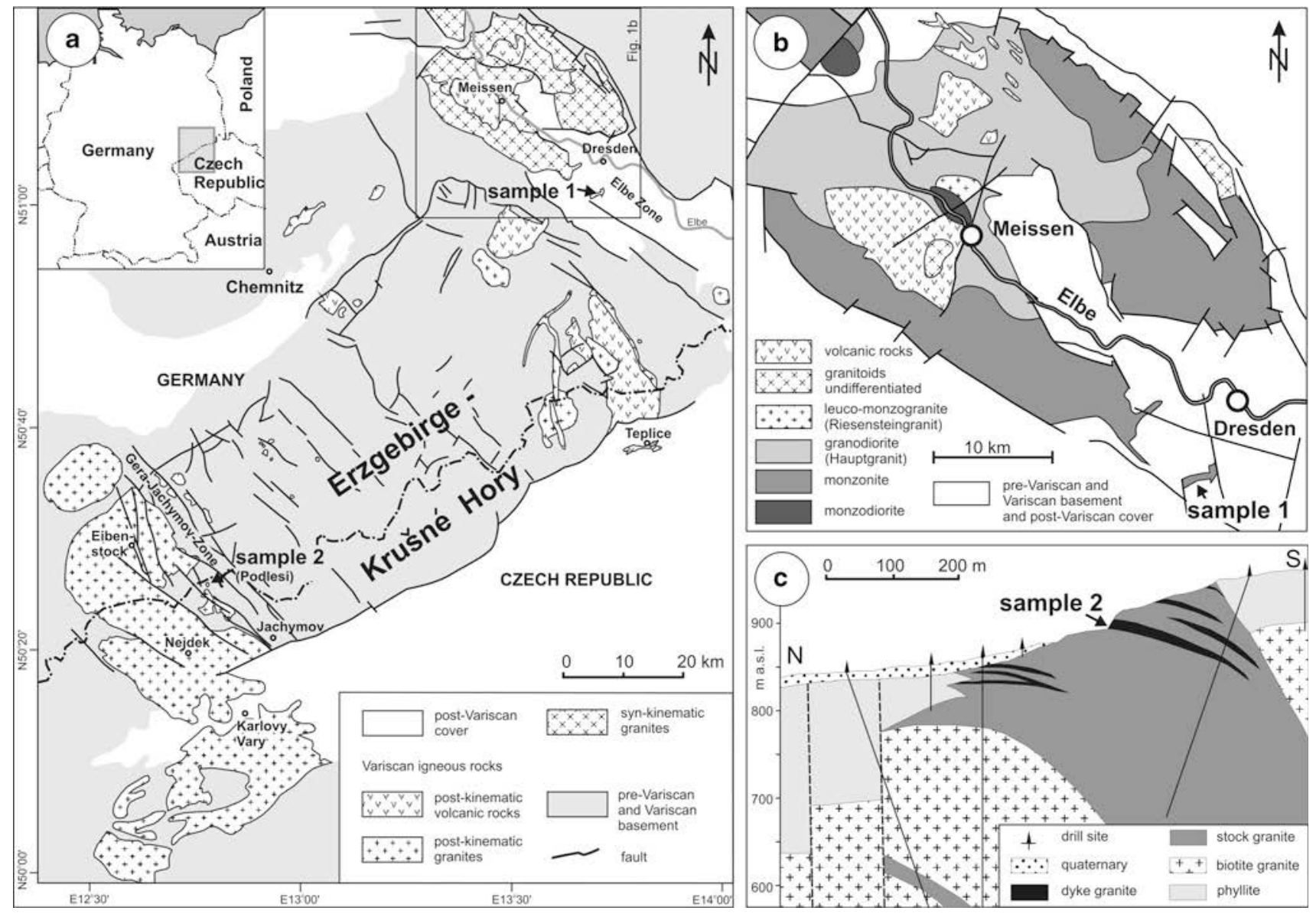

Fig. 1 a Simplified geological map of the Erzgebirge/Krušné Hory and adjacent regions showing the local distribution of late-Variscan granites and the two sample localities. The inset shows the location of the study area within central Europe. b Simplified geological map of the Meissen Massif according to Eilers et al. (2000). The monzonite

\section{Geological setting and petrography}

\section{Meissen monzonite}

The Meissen monzonite represents the oldest and main intrusion stage of the late-Variscan Meissen Massif NW of Dresden, Germany (e.g. Pfeiffer 1964; Wenzel et al. 1997; Fig. 1b). The plutonic complex of Meissen developed as a typical telescope intrusion with K-rich dioritic to mainly monzonitic rocks at the margin and granodioritic to granitic rocks in the centre. The rock composition of at least three main intrusion stages changed from dioritic/monzonitic, granodioritic/monzonitic ('Hauptgranit') to leuco-monzogranites ('Riesensteingranit') from the margin towards the centre of the Meissen Massif (Pfeiffer 1964; Wenzel et al. 1991). The NW-SE-striking pluton intruded a pull-apart structure of the Elbe Zone during regional dextral strikeslip tectonics (e.g. Pietzsch 1927; Mattern 1996; Linnemann and Schauer 1999). The Elbe Zone is interpreted as sample originates from the SE tail of the intrusion. c Geological cross-section of the Podlesí granite according to Breiter et al. (2005). The sample originates from a quarry in the central roof of the intrusion

being a Late-Carboniferous NW-SE-trending ductile shear zone (Rauche 1991; Mattern 1996), which formed along the northern margin of the Bohemian Massif.

${ }^{40} \mathrm{Ar} /{ }^{39} \mathrm{Ar}$ cooling ages of amphiboles $(329.1 \pm 2.8 \mathrm{Ma}$, $330.4 \pm 2.8 \mathrm{Ma}$, Wenzel et al. 1997$)$ and ${ }^{238} \mathrm{U} /{ }^{206} \mathrm{~Pb}$ SHRIMP ages of magmatic rims on zircons (326 $\pm 6 \mathrm{Ma}$, $330 \pm 5$ Ma, Nasdala et al. 1999; $334 \pm 3$ Ma, Hofmann et al. 2009) are indistinguishable; however, they demonstrate the intrusion of the monzonitic magmas during the uppermost Viséan. Muscovite of the 'Hauptgranit' and the 'Riesensteingranit' yielded ${ }^{40} \mathrm{Ar} /{ }^{39} \mathrm{Ar}$ plateau ages of $323.4 \pm 1 \mathrm{Ma}$ and $323.6 \pm 1 \mathrm{Ma}$ (Sharp et al. 1997).

Our sample originates from the SE tail of the intrusion at the valley Plauenscher Grund near the Felsenkeller brewery (Fig. 1b) and represents the syn-kinematic example of our study. The term 'syn-kinematic' is related to strike-slip tectonics of the Elbe Zone, being part of the final stage of the Variscan orogenesis and the formation of Pangaea (e.g. Linnemann and Schauer 1999; Hofmann et al. 2009). 
The sample is a fine- to medium-grained weakly porphyritic monzonite containing K-feldspar laths (1-6 mm long; 32-33 vol.\%), oligoclase (0.5-5 mm long; 43-44 vol.\%), edenitic and actinolitic amphibole (1-5 mm long; $14-15$ vol.\%), quartz (0.1-3.5 mm; 5-6 vol.\%), biotite $(<1 \mathrm{~mm} ; 1$ vol.\%) and diopside (0.6 vol.\%; quantified X-ray diffraction data; Figs. 2a, b, 3a). K-feldspar, oligoclase, edenitic amphibole and diopside form usually sub-hedral to euhedral phenocrysts embedded in a somewhat finer-grained groundmass. The large $(>2 \mathrm{~mm})$ euhedral crystals are interpreted as phenocrysts, i.e., they crystallised in different PTX environments prior to final magma emplacement as indicated by their variable core to rim composition (Wenzel et al. 1997). Occasionally, amphibole grains contain diopside cores due to mixing of K-rich shoshonitic magma and granitic crustal magma during an early stage of the monzonite evolution (Wenzel et al. 1997), which is additional evidence for the early crystallisation of the phenocrysts. The groundmass predominantly consists of weakly or non-deformed anhedral quartz, K-feldspar and plagioclase. Common accessory minerals are apatite, titanite, magnetite and zircon (altogether 3-5 vol.\%). Titanite forms up to 2-mm-long prisms (Fig. 3b). The monzonite exhibits a macroscopic SPO characterised by aligned euhedral feldspar laths, amphibole and titanite. The SPO at the pluton margin where the sample comes from is more pronounced.

Aggregates of anhedral quartz fill interstices between feldspar laths and amphiboles. The lacquer peel method reveals a weak SPO of the elongated quartz aggregates (Fig. 2b). The quartz shows deformation lamellae and subgrain formation due to rotation recrystallisation (e.g. Passchier and Trouw 2006; Fig. 3b, c). Tiny quartz veins fill the intracrystalline cracks of broken K-feldspar laths. Myrmekite aggregates are common at K-feldspar faces sub-parallel to the magmatic foliation.

\section{Podlesí dyke granite}

The Podlesí granite forms a small tongue-like, late-Variscan intrusion, which outcrops over an area of $0.3 \mathrm{~km}^{2}$ at the eastern margin of the Eibenstock-Nejdek pluton in the northwestern Czech Republic (Fig. 1a). It is the youngest (311 $\pm 1 \mathrm{Ma}$; Breiter et al. 2005) and most differentiated granite of the Eibenstock-Nejdek pluton and well studied regarding geochemistry, petrology and mineralogy (Breiter et al. 1997; Chlupáčová and Breiter 1998; Táborská and Breiter 1998; Breiter 2001, 2002; Maros et al. 2002; Müller et al. 2002; Breiter et al. 2005). The granite intruded slightly older biotite granites and Ordovician phyllites. The major part of the Podlesí intrusion consists of medium-grained albiteannite-topaz granite (stock granite). Several sub-horizontal dykes of albite-zinnwaldite-topaz granite (dyke granite) were intruded into the uppermost part of the stock granite (Fig. 1c).
The sample was taken from the dyke granite, which is exposed in a 7-m wide, sub-horizontal dyke in a small quarry near Podlesí. In the uppermost $50 \mathrm{~cm}$, the dyke shows prominent layers with unidirectional solidification fabrics (Breiter et al. 2005). The solidification fabrics comprise fan-like zinnwaldite, comb quartz and K-feldspar up to $6 \mathrm{~cm}$ length embedded in fine-grained granite. The sample originates from approximately $1 \mathrm{~m}$ below the upper contact and $0.5 \mathrm{~m}$ below the solidification fabrics.

The fine-grained dyke granite (Fig. 2c, d) consists of quartz drops $(0.1-1.5 \mathrm{~mm} ; 22-34.5$ vol.\%), zinnwaldite flakes (6.5-8 vol.\%), K-feldspar (33.5-39.5 vol.\%), albite prisms $(0.5-2 \mathrm{~mm}$ long; $18-26 \mathrm{vol} . \%)$ and topaz (3.5-6 vol.\%), embedded in a microcrystalline mixture of albite, K-feldspar, quartz and topaz (Breiter 2002; Fig. 3d). Breiter (2002) distinguished three K-feldspar generations within the dyke granite: (1) scarce perthitic phenocrysts with $0.15-0.20 \mathrm{wt} \% \mathrm{Rb}$ and $0.4 \% \mathrm{P}_{2} \mathrm{O}_{5}$, (2) euhedral comb crystals in layers with unidirectional solidification fabric with $0.3-0.4 \mathrm{wt} \% \mathrm{Rb}$ and $0.6-0.8 \mathrm{wt} \% \mathrm{P}_{2} \mathrm{O}_{5}$ and (3) abundant non-perthitic K-feldspar with $0.5-0.7 \mathrm{wt} \% \mathrm{Rb}$ and $0.8-1.5 \mathrm{wt} \% \mathrm{P}_{2} \mathrm{O}_{5}$. Generation (2) does not occur in the investigated sample. The rims of generation (3) are strongly enriched in $\mathrm{P}_{2} \mathrm{O}_{5}$ indicating late crystallisation from the residual P-rich dyke granite melt. Crystals of generation (1) presumably represent inherited phenocrysts from the Podlesí stock granite, because the composition of the phenocrysts resembles the composition of the phenocrysts in the stock granite (Breiter 2002).

SPO of minerals is invisible at the hand-specimen scale. At a microscopic scale, some of the larger albite prisms are semi-parallel to the dyke granite contacts, defining a weakly developed magmatic foliation. The lacquer peel method (Behr 1966) reveals minor cm-scale layers of variable quartz/feldspar ratio and crystal size (Fig. 2c, d). These layers are parallel to the magmatic foliation.

Quartz occurs as 'snowball' quartz, which is defined as isometric to ellipsoidal, late-magmatic crystals with concentrically entrapped groundmass minerals, mostly albite (Beus et al. 1962; Fig. 3e, f). Despite the generally isometric shape, the 'snowball' has complex, dendritic grain boundaries. Albite prisms are tangential to and envelop the 'snowball' quartz. The chemistry and CL characteristics of the 'snowball' quartz are different from that of the early crystallised quartz phenocrysts occurring in the stock granite (Müller et al. 2002). The structural and chemical features of the 'snowball' quartz imply that the crystals grew more or less in situ (Müller et al. 2002; Breiter et al. 2005), i.e., the features are indicative for highly evolved, fluid-rich magma (Müller and Seltmann 1999). The extrapolated solidus temperature of the dyke granite magma determined from melt inclusion studies is $610 \pm 26^{\circ} \mathrm{C}$ (Thomas et al. 1996). Cathodoluminescence imaging 
Fig. 2 a Photograph of a polished hand specimen of the Meissen monzonite showing shape-preferred orientation of amphibole (black) and $\mathrm{K}$-feldspar (pinkish white) crystals. b Black-and-white scan of the lacquer peel of the Meissen monzonite. The peel was made from a polished and HF-etched hand specimen (for the method, see Behr 1966). Anhedral quartz (black) fills cavities between aligned feldspar and amphibole (white; not distinguishable) and microcracks in feldspars. The arrow indicates the orientation of the magmatic foliation formed by aligned crystals. c Photograph of a polished hand-specimen photograph of the fine-grained Podlesí dyke granite. d Black-and-white scan of the lacquer peel of the Podlesí dyke granite. Quartz preferentially forms isometric and ellipsoid crystals. The weakly developed magmatic foliation (arrow) is indicated by variations in the quartz/feldspar (black/white) ratio
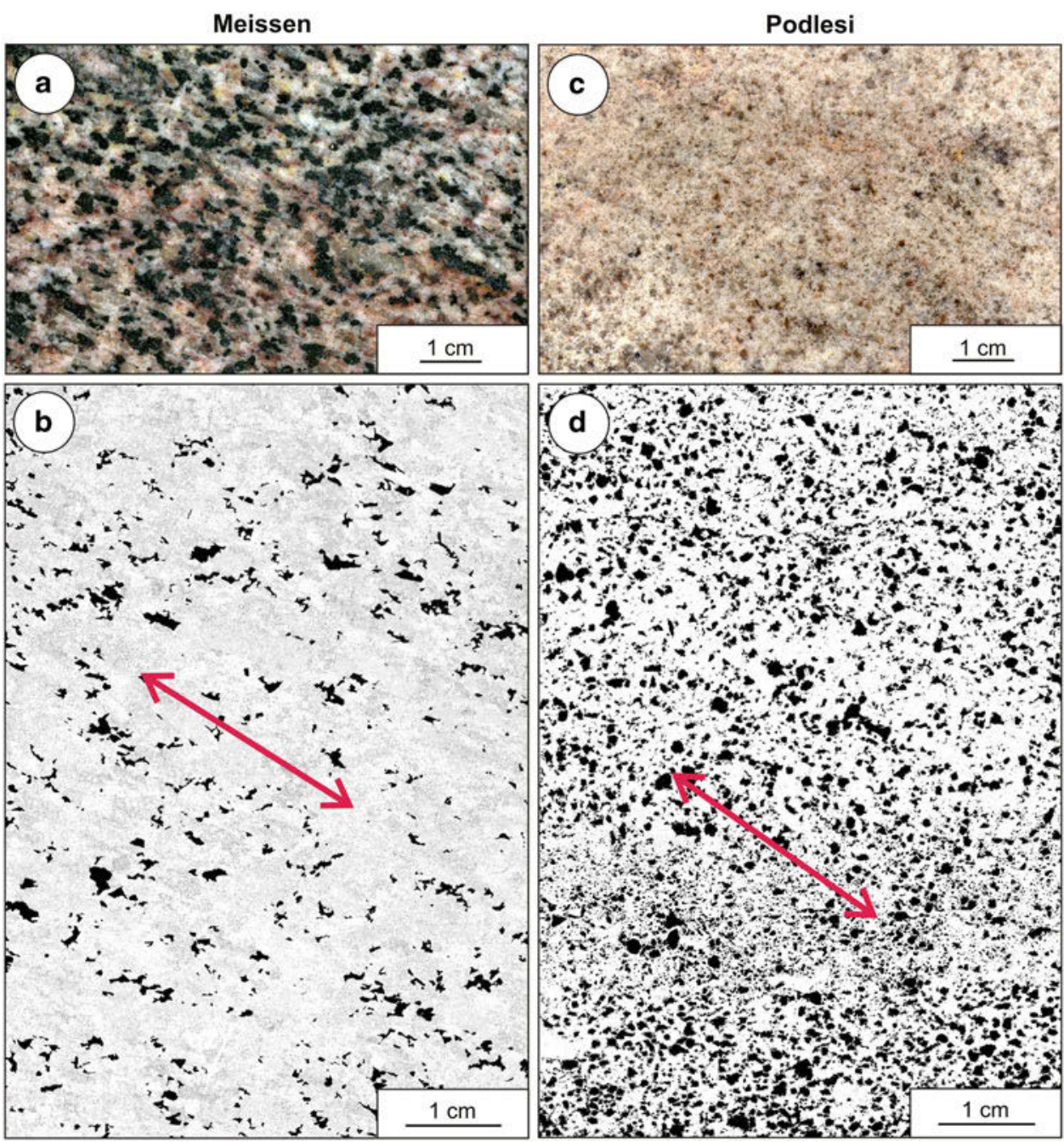

reveals intragranular oscillatory growth zoning with trigonal habit, indicating that the 'snowball' quartz crystallised in the low-quartz stability field (Fig. 3e). The temperature of the low/high-quartz transition is $573^{\circ} \mathrm{C}$ at $1 \mathrm{~atm}$ and increases with increasing crystallisation pressure (Yoder 1950). The pressure during emplacement of the Podlesí granite was about $1 \mathrm{kbar}$ (Breiter et al. 2005), which caused an increase in the transition temperature to $600^{\circ} \mathrm{C}$ (Yoder 1950). This temperature is within the error range of the magma temperature calculated from the melt inclusion data by Thomas et al. (1996).

\section{Methods}

LPO evaluation from neutron diffraction data

The diffraction experiments were carried out at the TOF diffractometer SKAT at the pulsed reactor IBR-2 in Dubna, Russia (Ullemeyer et al. 1998). Application of TOF neutrons offers the opportunity to record complete diffraction patterns, i.e., to measure all interesting pole figures simultaneously. The SKAT is, in particular, characterised by good $d$ resolution ( $d$ : lattice spacing) and by a large beam cross-section $\left(50 \times 50 \mathrm{~mm}^{2}\right)$. Both these characteristics were important for our investigations, because the granite samples are polyphase composites with constituents of low crystal symmetry and, therefore, the diffraction patterns contain many Bragg reflections (Fig. 4). In addition, the samples are rather coarse-grained, i.e., large sample volumes are required to ensure sufficient grain statistics. Cylindrical samples of about $50 \mathrm{~cm}^{3}$ were prepared for the diffraction experiment; in the case of the more coarse-grained Meissen monzonite, three cylinders $(40 \times 40 \mathrm{~mm})$ were measured, and the recorded diffraction patterns were summed up to improve grain statistics.

For Quantitative Texture Analysis (QTA) the WIMV algorithm was applied (Matthies and Vinel 1982). Despite optimal experimental conditions, QTA of polyphase rocks is crucial and was handled as an interactive procedure, because various combinations of input pole figures may lead to dissimilar results (Leiss et al. 2002). We, therefore, 
Fig. 3 a Fabric of the Meissen monzonite characterised by preferentially oriented

K-feldspar laths with twinning (kfs; crossed polarizers). am-amphibole. b Sub-grain formation in quartz (qtz) caused by local strain imposed by the neighbouring, more rigid amphibole (am; arrows; crossed polarizers). $t i$ titanite.

c Sub-grain formation in interstice quartz (qtz; crossed polarizers). $k f s$ K-feldspar, $p l$ plagioclase. d Fabric of the Podlesí dyke granite with droplike quartz ('snowball' quartz; qtz) embedded in a fine-grained groundmass of albite (crossed polarizers). e SEM-CL image of 'snowball' quartz (qtz) revealing oscillatory growth zoning with trigonal habit. Alteration caused the lowering of CL intensity (dark grey areas) at the crystal margins. The crystal is attached with the rhombohedral face to a zinnwaldite (zwd) flake. ab—albite. f 'Snowball' quartz (qtz) stitched to an albite plate ( $\mathrm{ab}$; crossed polarizers).

Euhedral and inclusion-rich topaz (toz) is common in the rock
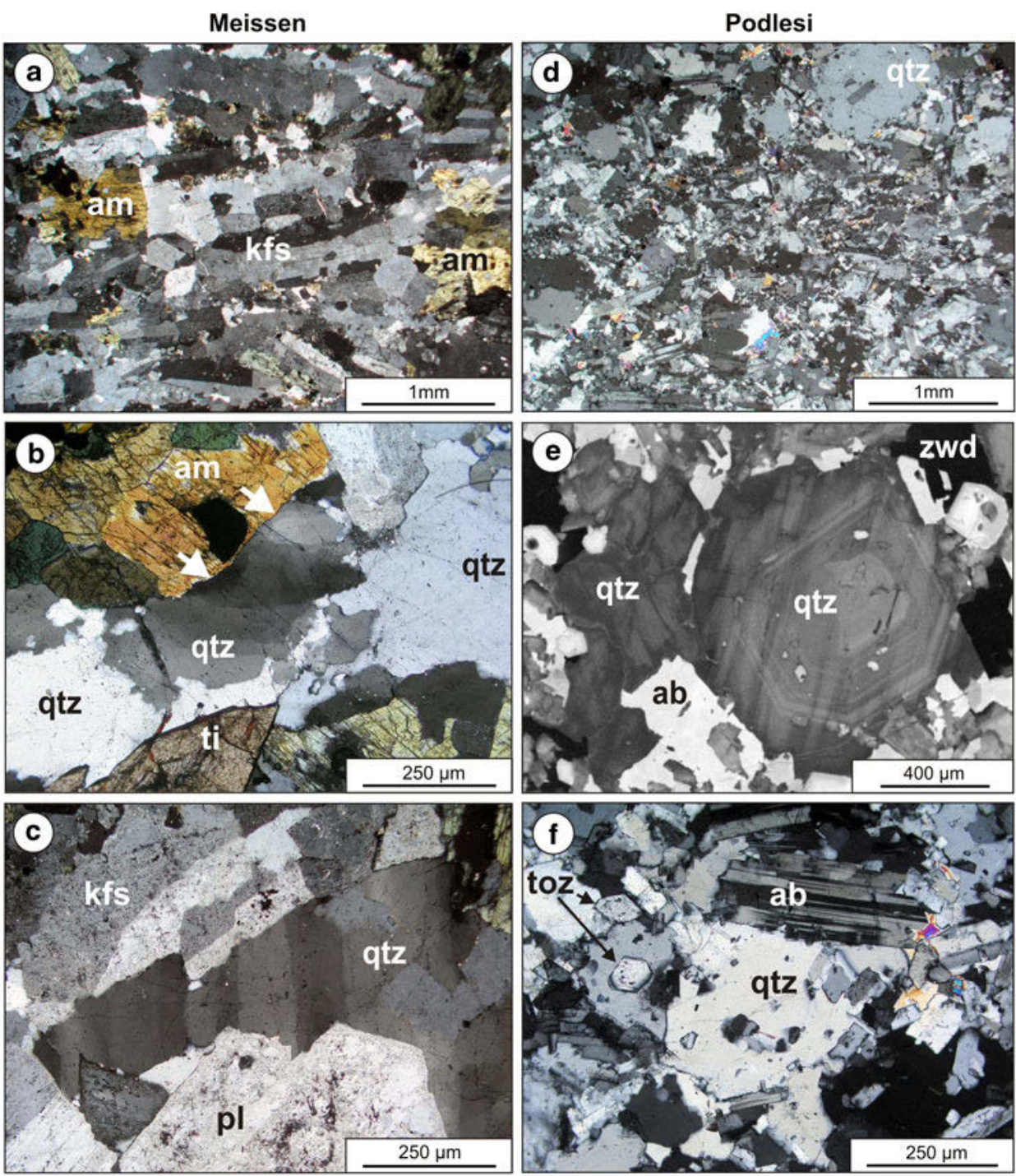

checked the outcome of several QTA runs with different input for reliability, which can be done by comparing the reproduction (RP) values (Matthies et al. 1988), and comparing recalculated pole figures to particular experimental pole figures not used for the calculations. Minimising the errors of LPO determination in such a way ensures the optimum reliability of the final result. The pole figures are presented such that the foliation plane/flow plane is horizontal and the reference joint plane is vertical (Figs. 5, 6).

Special attention was focussed on the quartz (011)(101) reflection of the Podlesí granite, which overlaps the zinnwaldite (001) basal plane reflection. The volume fraction of zinnwaldite approaches $6.5-8$ vol. $\%$. Assuming preferred orientation of the basal planes parallel to the foliation plane/flow plane, which must be expected due to the grainshape-related re-orientation mechanism of micas, the intensity maximum close to the foliation pole in the quartz rhomb pole figure is partly due to the zinnwaldite (001) reflection. Hence, the region around the foliation pole was excluded from QTA of quartz, as indicated by a dotted small circle in the quartz rhomb pole figure (Fig. 6). Finally, the kinematically significant pole figures of all the phases where QTA was possible were calculated from the orientation distribution function.

Special attention was also put on the quartz (011)(101) reflection of the Meissen granitoid. Due to the low volume fraction of quartz (5-6 vol.\%), the strong (011)(101) reflection was the only reflection, which could be used to construct a reliable pole figure. All the other quartz reflections are either too low in intensity or could not be separated from the reflections of the other mineral phases. For trigonal crystal symmetry, QTA with a unique solution is not possible from a single pole figure (Helming 1992). 
Fig. 4 Time-of-flight diffraction pattern of the Podlesí dyke granite showing the large number of Bragg reflections of polyphase rock samples. Prominent Bragg reflections are labelled; reflections used for the QTA are bold faced

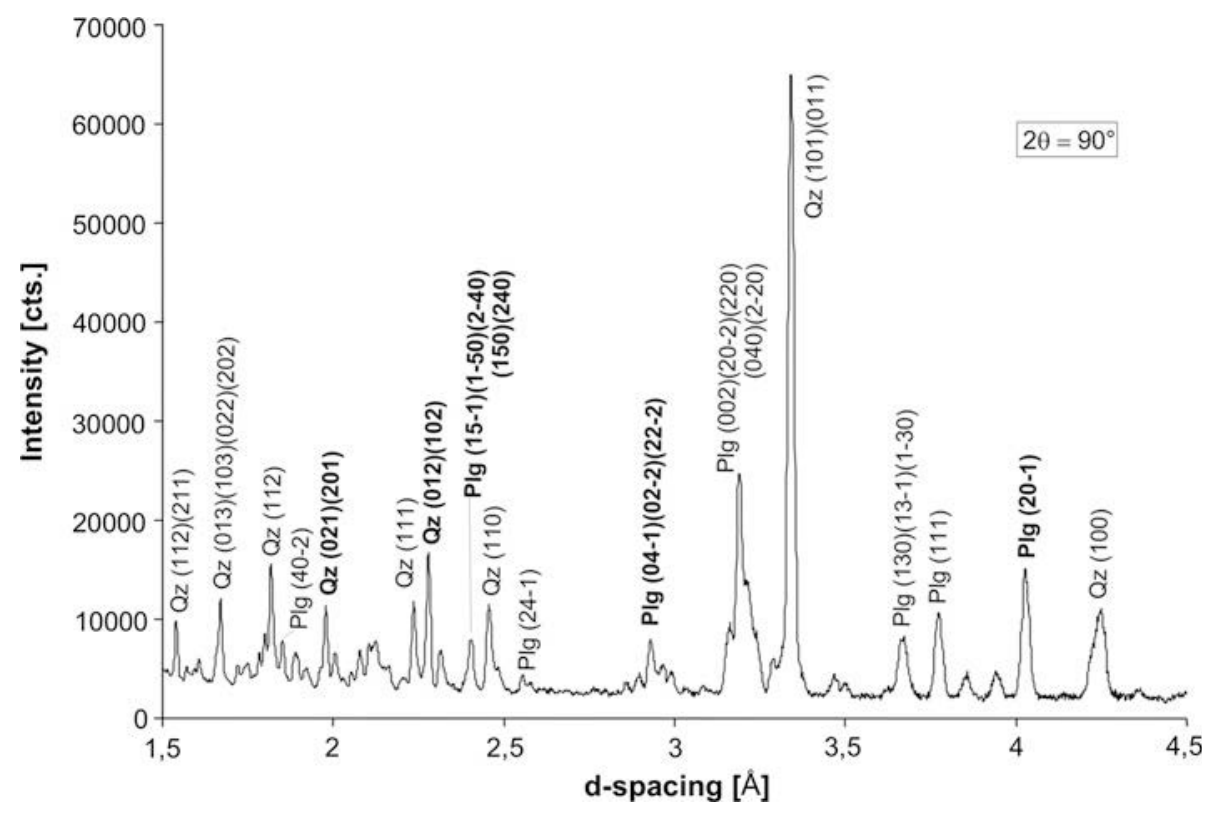

However, to determine how the $c$-axes distribution may appear, we calculated the orientation distribution function from the (011)(101) pole figure applying the WIMV algorithm and compared the significant recalculated pole figures to particular pole figures obtained by means of texture component deconvolution (Helming and Eschner 1990; for applications, see e.g. Leiss et al. 2002, Leiss and Molli 2003). Each algorithm for QTA is characterised by specific errors leading to somewhat dissimilar results; however, similarities between recalculated pole figures can be used to define a semi-quantitative estimate of the $c$-axes distribution of interested.

Scanning electron microscope cathodoluminescence (SEM-CL)

SEM-CL images were obtained from the JEOL 5900LV analytical SEM with an attached GATAN Mini-CathodoLuminescence detector at the Natural History Museum of London. The applied acceleration voltage and current was $20 \mathrm{kV}$ and $\sim 1 \mathrm{nA}$, respectively. The images were collected from 4 scans of $20 \mathrm{~s}$ photo speed each and a processing resolution of 1280 by 960 pixels and 256 grey levels.

\section{Results of LPO analyses}

Meissen monzonite

The experimental pole figures of K-feldspar and plagioclase of the Meissen monzonite display more pronounced
LPOs, whereas the LPO of edenite (only the (040) pole figure could be extracted from the TOF patterns without overlaps) appears to be less pronounced (Fig. 5). The only experimental pole figure of quartz (011)(101) shows a three-fold maximum distribution, which is symmetrical with respect to the magmatic foliation plane; the degree of preferred orientation is weaker compared to the feldspars. The 'WIMV'-derived and 'components'-derived recalculated (011)(101) pole figures are very similar to the experimental pole figure; however, the recalculated $c$-axes pole figures show distinct differences. While it seems to be clear that the $c$-axes form a great-circle distribution subparallel to the foliation plane with evidence for maxima on the great circle, the pole figure recalculated from the WIMV-ODF reveals an additional maximum normal to the foliation plane. This maximum cannot be reproduced with the component method.

Because of the pronounced LPOs, all experimental oligoclase and K-feldspar pole figures shown in Fig. 5 were applicable to QTA. Recalculated (010) pole figures of both minerals display a very strong maximum parallel to the foliation normal. The (100) and (001) faces of K-feldspar display uniform intensity distributions on great circles around the (010) maximum. Due to weaker LPO, the (100) girdle of oligoclase is broader, and the (001) girdle degenerates to a small circle around the (010) maximum. Preferred orientation of both these lattice planes is not a direct consequence of the active deformation process, because the intensity distributions on the great circle/small circle are uniform. This holds true for K-feldspar and the edenite (040) pole figure as well. Concerning edenite, the consequence is that no information about the active 

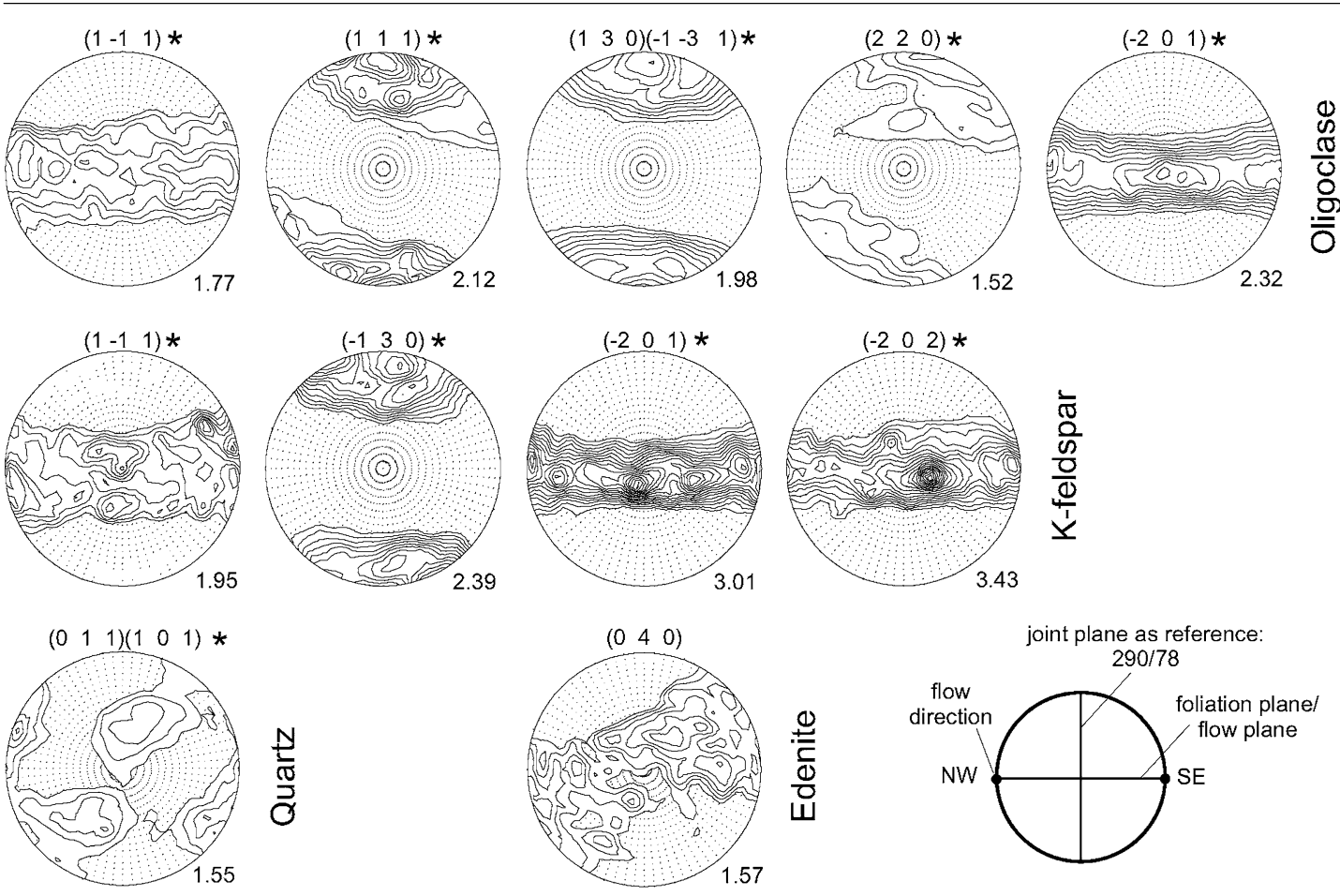

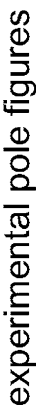
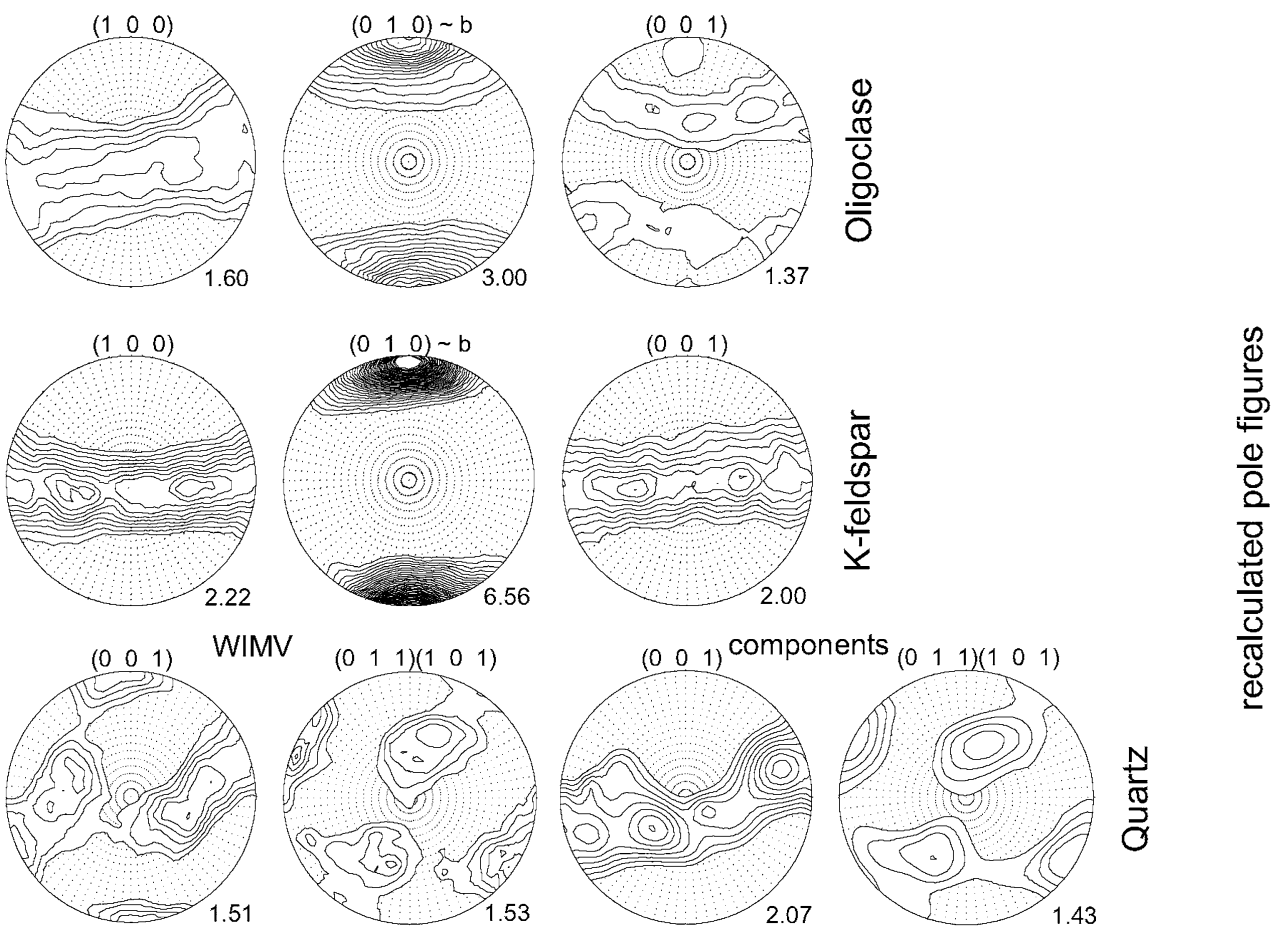

Fig. 5 Experimental (oligoclase, K-feldspar, quartz, edenite) and recalculated (oligoclase, K-feldspar, quartz) pole figures in the Meissen monzonite. Units are multiples of a random distribution; the maximum intensity is indicated at the bottom right. Pole figures

re-orientation mechanism could be obtained from the LPO. The observed parallelism of the (010) faces of oligoclase, $\mathrm{K}$-feldspar and edenite and the macroscopic magmatic indicated with an asterisk were used for QTA. Orientation of the pole figures with respect to the reference joint plane $290^{\circ} / 78^{\circ}$ and to the foliation plane is indicated by a sketch diagram

foliation is the most significant result of the LPO analyses. The recalculated pole figures of the feldspars do not indicate a magmatic lineation. 

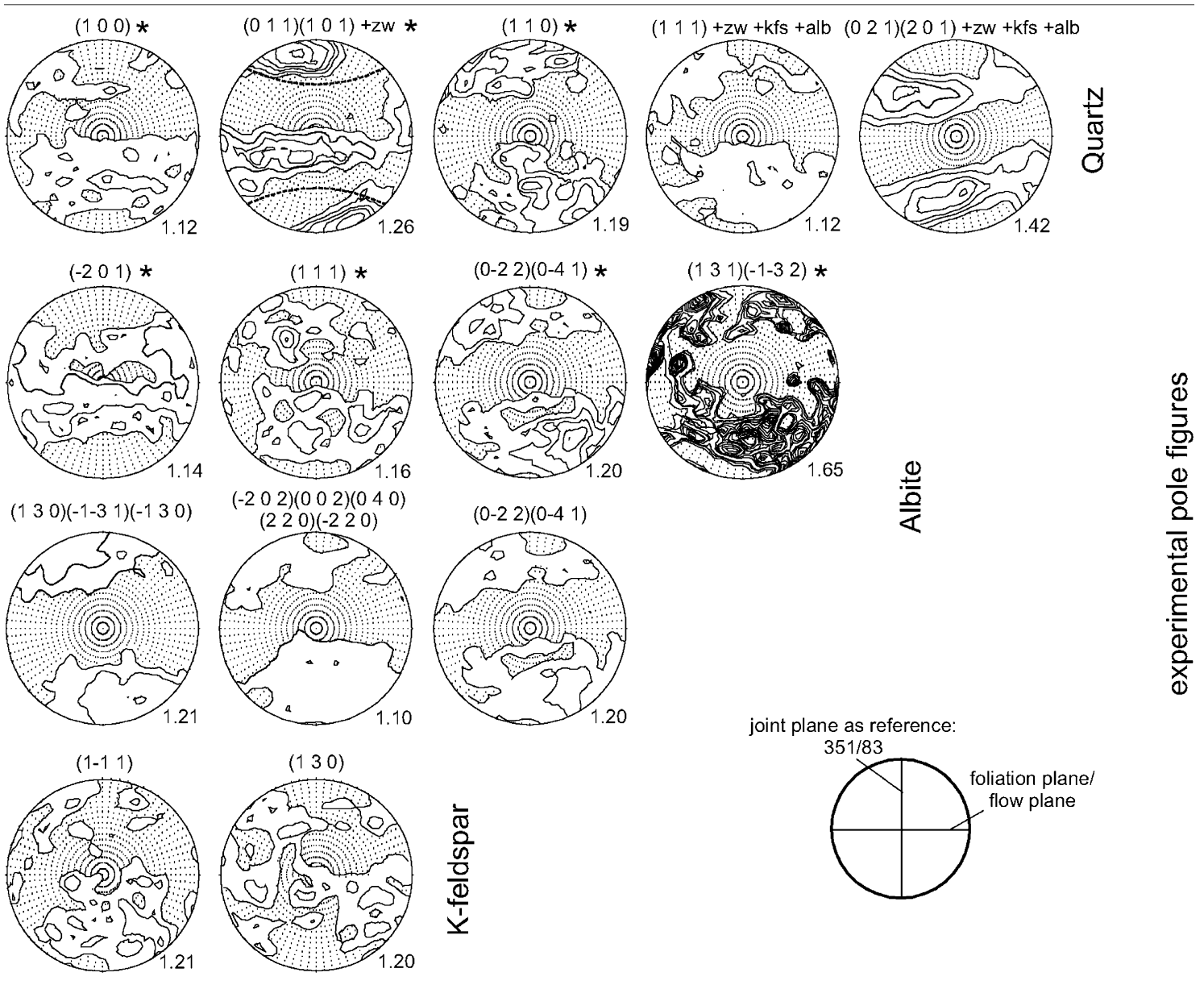

joint plane as reference:
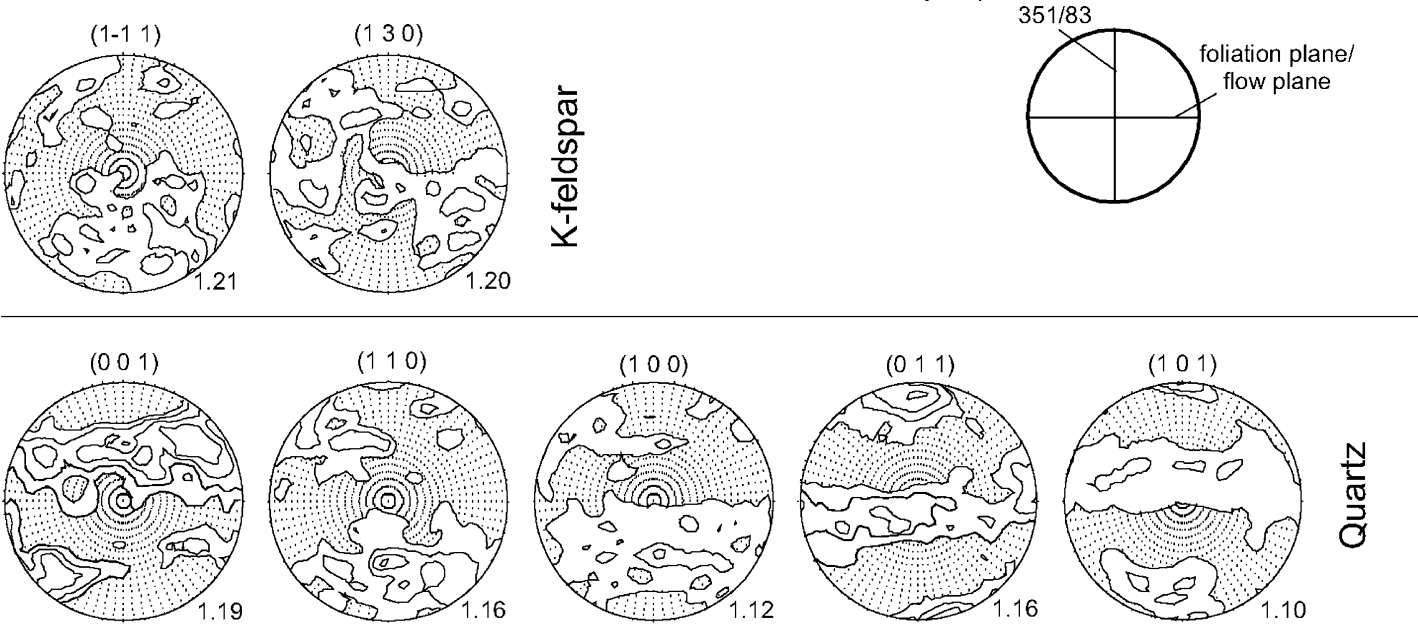

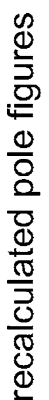
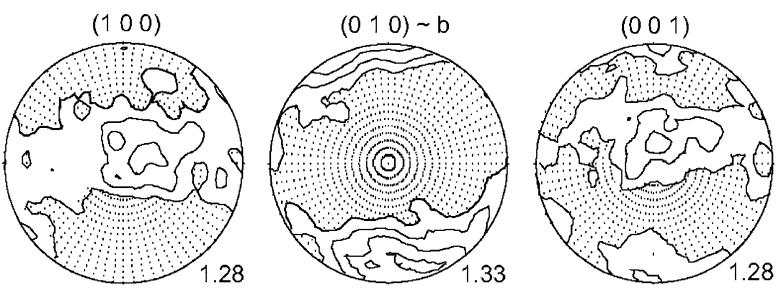

$\frac{\stackrel{0}{\frac{0}{2}}}{\frac{1}{4}}$

$\frac{0}{\frac{0}{5}}$

Fig. 6 Experimental (quartz, albite, K-feldspar) and recalculated (quartz, albite) pole figures in the Podlesí dyke granite. Orientation of the pole figures with respect to the reference joint plane $351^{\circ} / 83^{\circ}$ and

\section{Podlesí dyke granite}

The quartz and albite experimental pole figures of the Podlesí dyke granite show very weak but distinct preferred orientations, which are more or less symmetrically arranged to the assumed sub-horizontal foliation plane is indicated by a sketch diagram. For further explanations, refer to Fig. 5

with respect to the macroscopic reference joint plane $351 \% 83^{\circ}$ (plunge direction/plunge angle). In contrast, the $\mathrm{K}$-feldspar pole figures appear to be random (Fig. 6). As mentioned earlier, the zinnwaldite (001) reflection overlaps the quartz (011)(101) reflection. The postulate that the 
intensity maximum close to the foliation pole is partly due to the preferred orientation of the zinnwaldite (001) reflection is supported by the $(021)(201)+\mathrm{zw}+\mathrm{kfs}+$ alb pole figure (Fig. 6), which shows a small-circle intensity arrangement around the intensity maximum in the $(011)(101)+\mathrm{zW}$ pole figure. Crystal structure calculations for all the minerals present in the sample indicate that the intensity distribution of the (021)(201) $+\mathrm{zw}+\mathrm{kfs}+$ alb pole figure is dominated by some low-indexed zinnwaldite reflections with an angular distance of $30^{\circ}$ to $60^{\circ}$ to the basal plane normal. Hence, the small-circle intensity distribution in the (021)(201) $+\mathrm{zw}+\mathrm{kfs}+$ alb pole figure indicates missing preferred orientation of particular zinnwaldite reflections, as well as preferred orientation of the zinnwaldite basal planes with the intensity maximum in the centre of the small circle. Since QTA of zinnwaldite was not possible due to insufficient input information, we cannot quantify the basal plane preferred orientation of zinnwaldite.

QTA of quartz was based on three experimental pole figures marked with an asterisk (Fig. 6). None of the other pole figures could be used due to multiple overlaps (see examples in Fig. 6). However, the results appear to be reliable, mainly due to the very small RP values (refer to Leiss et al. (2002) and to discussion in "LPO evaluation from neutron diffraction data"). The $c$-axis orientations of quartz form an incomplete small-circle pattern around the foliation normal with a large opening angle. Correspondingly, the $a$-axes cluster in poorly defined small circles around the foliation normal with a large opening angle. The separated (101) and (011) rhombohedral faces display girdle distributions sub-parallel to the foliation plane and cluster-like maxima close to the foliation normal.

With regard to the recalculated pole figures of albite, the (010) faces display the most pronounced LPO with its normals sub-parallel to the foliation normal (Fig. 6recalculated pole figures). The deviation is about $20^{\circ}$. This is in agreement with the orientation of the cluster-like (011) intensity maximum of quartz. All the other pole figures of albite show weaker, girdle-like intensity distributions. The (010) face is the face with the largest surface area of idiomorphic albite. Hence, it must be discussed whether the LPO of albite may originate in the same way as for quartz.

In summary, the most important results of the LPO analyses are the parallelism of (101) and (011) rhombohedral faces of quartz, (010) faces of albite, magmatic foliation and sub-horizontal contacts of the granite. The intensity distributions are more or less symmetrically arranged with the symmetry axis normal to the assumed flow plane. Moreover, the supposed basal plane preferred orientation of zinnwaldite confirms that the macroscopic magmatic foliation plane observed in the field is also significant at a sample scale.

\section{Discussion}

\section{Meissen monzonite}

The magma of the Meissen monzonite intruded the stress field of the active dextral strike-slip system of the Elbe Zone (e.g. Mattern 1996; Linnemann and Schauer 1999) with high crystal load ( $>25$ vol\% phenocrysts), whereas the Podlesí granite stock emplaced in a relatively passive, transtensional tectonic setting (see also "Implications for the regional geology"). However, the LPO of plagioclase in the Meissen monzonite is similar to the LPO of albite in the Podlesí dyke granite; this holds true for the type of LPO and for the orientation of the contour line patterns with respect to the magmatic foliation. The similar LPO of nonequidimensional plagioclase crystals in both magmatic systems suggests that the crystal alignment was caused by magma flow.

The crystal load of the monzonitic magma during emplacement was presumably higher than $25 \mathrm{vol} . \%$, as indicated by the rather large volume fraction of euhedral amphibole and feldspar phenocrysts. Phenocrysts act as rigid particles in a viscous fluid and may be aligned if the crystals own non-equidimensional shapes. This requires that the phenocrysts crystallised early, which is documented by different composition and structure compared to the groundmass minerals, and by internal compositional zoning (e.g. Davidson et al. 2008). Early crystallisation of the amphibole and feldspar phenocrysts in the monzonite magma is indicated by variable core to rim composition, the occurrence of diopside cores in amphibole grains and different compositions of groundmass and phenocryst feldspars (Pfeiffer 1964; Wenzel et al. 1997).

Due to the high crystal load of the monzonitic magma, the crystals could not freely rotate and were tiled against each other. As soon as the interaction between the crystals became predominant, the flow regime changed from laminar to granular flow (e.g. Drake 1990). However, we suggest that the very pronounced LPOs of K-feldspar and plagioclase phenocrysts are caused by a combination of internal shear stress due to magma flow dynamics and external shear stress due to regional strike-slip tectonics of the Elbe Zone. The more distinct magmatic foliation at the intrusion margin of the Meissen Massif compared to the core of the pluton (e.g. Behr 1968) is a strong indication that regional shear stress imposed the shear stress caused by magma dynamics (Vigneresse et al. 1996). Plastically deformed (elongated) xenoliths with their long axis parallel to the magmatic foliation plane (Pfeiffer 1964) are other indicators for superimposition of the internal stress field by the regional stress field. The primary magmatic flow plane and the foliation caused by the regional shear tectonics are parallel to each other, suggesting that the direction of 
magma flow was controlled by the regional shear tectonics already at the initial stages of the pluton emplacement.

Deformation lamellae, sub-grain formation due to rotation recrystallisation in quartz and strain-related myrmekites are features of solid-state flow (Simpson 1985; Vernon 2000), indicating that the regional shearing continued after the rheologically critical melt percentage (RCMP) of the monzonitic magma was exceeded. The RCMP delineates the boundary between magmatic and tectonic fabrics and is defined for $65-80 \%$ solids (crystals) in the magma (Arzi 1978; van der Molen and Paterson 1979).

Conclusions on the development of the quartz LPO of the Meissen monzonite are hard to draw, because 'WIMV'derived and 'components'-derived recalculated $c$-axes pole figures show significant differences (Fig. 5). The component method reveals a broad great-circle distribution of the $c$-axes sub-parallel to the foliation plane, whereas the WIMV method shows an additional weak $c$-axis maximum normal to the foliation plane. According to Pfeiffer (1964), quartz crystallised at the final stage of magma solidification. Microstructural indicators for the late crystallisation of quartz are as follows : (1) the small grain size and anhedral shape of the grains filling interstices between feldspar laths and amphiboles, (2) quartz moulded onto the crystal phases of adjacent grains, (3) quartz fills the cracks of broken feldspar phenocrysts and (4) quartz shows homogeneous CL (early quartz phenocrysts would show concentric growth zoning in CL, e.g. Müller et al. 2009). Thus, the alignment of quartz nuclei and/or small equidimensional quartz crystals due to magmatic flow can be excluded.

The uniform great-circle distribution of the $c$-axes subparallel to the foliation plane may result from oriented quartz nucleation under the influence of an anisotropic stress field, as predicted by Kamb's hypothesis (1959). Based on thermodynamic calculations, Kamb (1959) concluded that the $c$-axis of quartz tends to align perpendicular to the maximum principle pressure axis and, thus, subparallel to the foliation plane. Kamb (1959) calculated small-circle $c$-axis distributions with the circle axis perpendicular to the foliation plane, but the quartz $c$-axes of the Meissen monzonite form a uniform great-circle distribution. As mentioned before, the solidifying monzonite magma was continuously affected by the regional shear tectonics. After the RCMP was exceeded, the strain partitioned into interstices between the rigid feldspar and amphibole crystals, where the quartz was still crystallising. The local stress field could result in oriented quartz growth, whereby the strongest axis ( $c$-axis of quartz) tended to align perpendicular to the principle pressure axis as it is illustrated in Fig. 7a.

Nevertheless, the LPO geometry of the Meissen quartz does not imply a typical deformational LPO (e.g. Schmid and Casey 1986), indicating that the solid-state flow features observed in quartz are not strong enough to explain a significant crystallographic re-orientation of quartz. We cannot entirely exclude that the quartz LPO is partially due to solid-state flow, such as local recrystallisation at grain edges and sub-grain formation (Figs. 3b, c). The myrmekite formation, being part of the observed solid-state features, may have influenced the quartz LPO. However, myrmekites grow in epitaxial continuity with parent crystals (e.g. Stel and Breedveld 1990); thus, the myrmekite formation had no influence on the bulk LPO of quartz.

The poorly defined quartz $c$-axis maximum perpendicular to the foliation plane, calculated by the WIMV method, may reflect a different growth process. The most probable explanation is epitaxial growth on the strongly aligned feldspars, whereby quartz nucleated with its $c$-axis (basal plane) perpendicular to (010) and/or (110) feldspar faces (Fig. 7b). This type of epitaxial growth is known, for example, from graphic feldspar-quartz intergrowth (e.g. Fenn 1986; Stel 1992) and macroscopic quartz crystal overgrowths on feldspar (e.g. Akhavan 2010). Particular LPO developed presumably in pressure shadows between aligned and tiled feldspar phenocrysts. Nevertheless, the interpretation of the quartz LPO is rather speculative because of reflection overlaps in the diffraction pattern and the low volume fraction of quartz (5 to 6 vol.\%) resulting in a weak diffraction signals. Evidence for a magmatic lineation could not be obtained from the LPOs.

\section{Podlesí dyke granite}

Melt inclusion studies by Breiter et al. (1997) revealed that the dyke granite magma initially contained up to $2.6 \mathrm{wt} \%$ P, 2.2 wt $\% \mathrm{~F}$ and about $7.5 \pm 0.8$ eq.-wt $\%$ water. The magma chemistry indicates a rather low viscosity of the dyke granite melt at the time of emplacement (e.g. Dingwell 1987). In addition, the magma had a low crystal load of 10 to $15 \mathrm{vol} . \%$, comprising quartz, albite, mica nuclei and some K-feldspar phenocrysts inherited from the stock granite magma (Breiter 2002; Breiter et al. 2005). Distinct compositional zoning of $\mathrm{K}$-feldspar phenocrysts and different chemistry compared to the groundmass K-feldspar document crystallisation during an early stage of magma evolution (Breiter 2002).

After emplacement, the pressure of dissolved $\mathrm{H}_{2} \mathrm{O}$ within the dyke exceeded the lithostatic pressure and the cohesion of surrounding rocks, leading to fracturing and brecciation in the apical part of the 7-meter-thick dyke where the sample originates (Breiter et al. 2005). The sudden drop of pressure during degassing caused rapid crystallisation of the strongly under-cooled melt. Triggered by microseismicity and filter pressing, more granite magma moved into contact-parallel spaces generated by the 


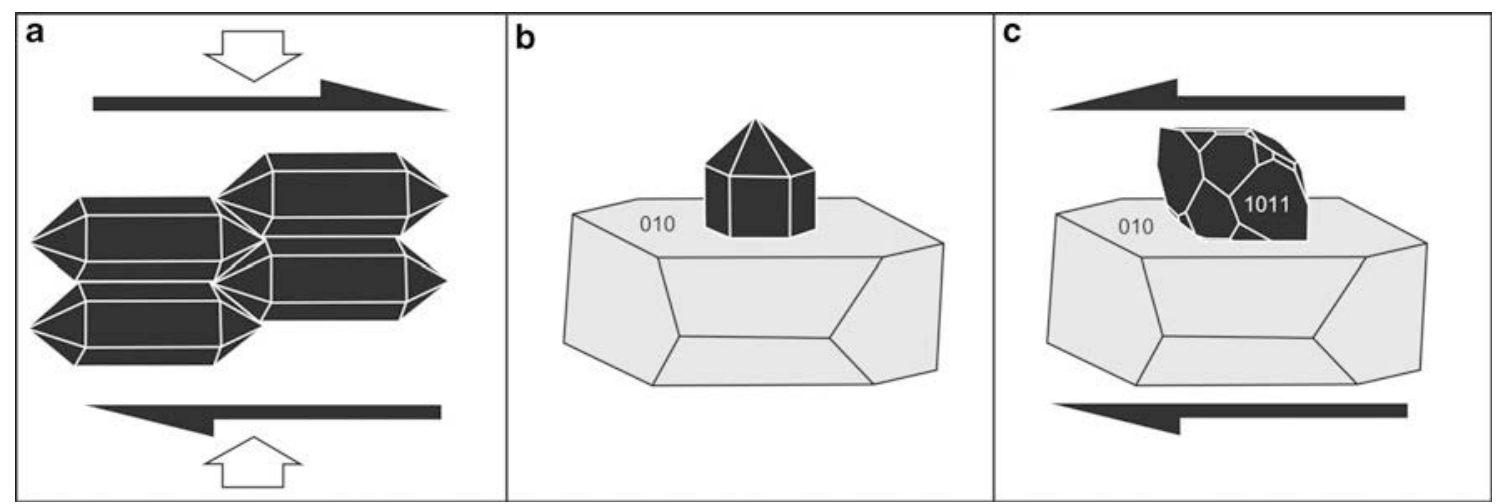

Fig. 7 Schematic illustrations of supposed processes resulting in quartz LPOs detected in the Meissen monzonite (a and b) and Podlesí granite (c). a Oriented high-quartz nucleation and growth under the influence of an anisotropic stress field according to Kamb's hypothesis (1959). b Epitaxial growth of high-quartz (black) on aligned feldspar (grey), whereby quartz nucleated with its $c$-axis (basal plane) perpendicular to (010) and/or (110) feldspar faces. c Adherence of the rhombohedral faces of trigonal quartz to the (010) faces of aligned feldspar. Due to shape anisotropy of their attachments, quartz crystals were passively aligned during magma flow. The quartz of the Podlesí granite crystallised as trigonal low-quartz. For explanations, see text

approximately fits the LPO geometry in the flattening field of the local strain field (e.g., Schmid and Casey 1986). The opening angle of the two small girdles formed by the $c$-axes in the pole figure is approximately $120^{\circ}-140^{\circ}$ (Fig. 6). This angle corresponds to the angle between the rhombohedral faces.

Quartz LPOs showing small-circle $c$-axis distributions were already observed for a number of late-Variscan and post-kinematic granites of the Bohemian Massif (Maroscheck 1933; Behr 1967; 1968; Watznauer and Behr 1966; Mierzejewski 1968). Mostly, these granites are weakly porphyritic, medium- to coarse-grained, with K-feldspar and quartz phenocrysts embedded in a finer-grained groundmass. Watznauer and Behr (1966) distinguished between the $c$-axes LPO of high-quartz (early-magmatic phenocrysts) and low-quartz (groundmass quartz) forming small-circle distributions with small and large opening angles, respectively. The $c$-axes LPO of high-quartz is less pronounced than the LPO observed for low-quartz in the same rock. The $c$-axis opening angle of the quartz LPO of the Podlesí granite corresponds to the low-quartz LPO pattern, which is in agreement with the observed low-quartz habit of the 'snowball' quartz. According to Watznauer and Behr (1966), the axis of the open circles is mostly parallel to the magmatic lineation, sometimes perpendicular to the magmatic lineation and foliation (e.g., Berbersdorf granite, Granulite Massif, Germany). The latter geometry corresponds to the LPO geometry of the Podlesí granite.

Maroscheck (1933) suggested that the quartz LPO in the Mauthausen granite of the South Bohemian Massif is caused by the alignment of crystal nuclei in a crystal mush during magmatic flow ("Keimregelung"). However, he could not explain the mechanism leading to preferred 
orientation of the more or less isotropic quartz nuclei. Watznauer and Behr (1966) and Behr (1968) suggested that the quartz LPOs are either due to the alignment of crystal nuclei by magmatic flow forced by the internal stress of intruding magma and/or the LPOs represent a stable state of thermodynamic equilibrium according to Kamb's theory (1959). The authors exclude regional shearing and twinning as possible causes for the small-circle $c$-axis distribution.

The alignment of the (101) and (011) rhombohedral faces of 'snowball' quartz in the Podlesí dyke granite parallel to the magmatic foliation (Fig. 6) implies both the processes described by Watznauer and Behr (1966) and Behr (1968): (1) 'snowball' quartz alignment due to magmatic flow and/or (2) oriented crystal growth under stress according to the Kamb's hypothesis (1959). The Podlesí quartz does not exhibit recrystallisation, grain-size reduction, sub-grain formation, myrmekites, etc., which are evident for solid-state flow (Vernon (2000). Hence, solidstate flow as re-orientation mechanism can be excluded. Alignment due to magmatic flow is difficult to understand because the quartz crystals are a more or less isotropic. However, the surface of the rhombohedral faces is larger than the surface of the prism faces, as visualised by SEMCL imaging (Fig. 3e). Thus, the rotation of crystals with one rhombohedral face parallel to the magmatic flow plane may explain the LPO to some extent. The 'snowball' quartz is commonly attached with its rhombohedral faces to the (010) faces of aligned albite prisms (Figs. 3e, f) and to the (001) face of mica flakes (Fig. 3e). However, quartz did not use the crystals of other minerals as nuclei, because it usually forms double-ended crystals (Fig. 3e). Moreover, quartz germinates with the $c$-axis perpendicular to feldspar and mica faces, which is not supported by the LPO geometry (see also discussion earlier). Therefore, it is suggested that the rhombohedral faces of the 'snowball' quartz adhered to the (010) faces of the strongly aligned albite and to the (001) faces of zinnwaldite during growth. Due to shape anisotropy of their attachments, quartz crystals were passively aligned during magma flow. Alternatively, the quartz LPO can be the result of oriented growth on faces of aligned albite and zinnwaldite grains. However, such type of oriented epitaxial growth has not been reported.

Implications for the regional geology

The Meissen monzonite and Podlesí granite intruded the Saxothuringian Erzgebirge at different geotectonic events post-dating the Variscan metamorphic peak at approximately 340 Ma (e.g. Romer et al. 2003). The Meissen monzonite intruded at $334 \pm 3 \mathrm{Ma}$, when large-scale strike-slip processes, the final events of the Variscan orogeny and formation of Pangaea took place (e.g. Kroner et al. 2007). The Podlesí granite intruded at $311 \pm 1 \mathrm{Ma}$ as the youngest intrusion of the Eibenstock-Nejdek pluton during orogenic uplift, extension and basement exhumation.

The Meissen Massif intruded an area of extension (pullapart structure) within the schist belt of the Elbe Zone during ongoing dextral shear (Mattern 1996; Kroner et al. 2007). The strain caused by the strike-slip movements lead to alignment of the magmatic foliation parallel to the shear direction at the NE and SW margin of the monzonite intrusion (Fig. 8). The magmatic foliation is sub-parallel to the $\mathrm{s}_{1}$-foliation of the host rocks at the NE and SW contact. The core of the intrusion is characterised by a concentric structure of the magmatic foliation, which seems to be less unaffected by the regional shear strain. Similar conclusions can be drawn from the orientation of the magmatic lineation. At the NE and SW margins of the intrusion, the magmatic lineation preferentially strikes NW to N, whereas in the core the lineation forms a radial pattern. Thus, the magmatic structures are, to some extent, mechanically coupled to the host rock structures according to the classification of Paterson et al. (1998).

The shear tectonics completed prior to intrusion of the Meissen 'Hauptgranit', the Meissen 'Riesensteingranit' and the Markersbach granite (30 km SE from the sample locality) into the Elbe Zone at $323.4 \pm 1 \mathrm{Ma}, 323.6 \pm 1 \mathrm{Ma}$ and $327 \pm 4 \mathrm{Ma}$ (Sharp et al. 1997; Hofmann et al. 2009). This is evident from the less-developed magmatic foliation of the particular granites, which is discordant to the host rock structures. Furthermore, they cross-cut the tectonic structures related to the dextral strike-slip event (Behr 1964; Hofmann et al. 2009). Thus, the intrusion of the Meissen monzonite is an important geological time marker during Variscan orogenesis.

The Eibenstock-Nejdek pluton, the mother pluton of the Podlesí intrusion, consists of stacked laccolith-like intrusions building up an approximately 10-km-thick pluton, indicated by seismic reflection data and the gravity anomalies (Bankwitz and Bankwitz 1994; Behr et al. 1994; Blecha et al. 2009). The tongue-shaped Podlesí granite stock resembles the generally laccolith-like intrusion style of the Eibenstock-Nejdek pluton, as indicated by field data, drill core data and sub-horizontal orientation of the magmatic foliation.

In contrast to the Meissen monzonite, the Podlesí granite stock emplaced in a rather passive, transtensional tectonic setting. No macroscale indications for a deformation-related intrusion were found. The magmatic structures (foliation and lineation) of the Podlesí granite and the Eibenstock-Nejdek pluton are discordant to the $\mathrm{s}_{1}$-foliation of the host rocks (Fig. 9a). It seems that the magmatic structures are completely decoupled from the ductile 
Fig. 8 a Simplified geological map of the Meissen Massif showing the deformation fabrics of the syn-kinematic intrusive rocks (magmatic foliation and lineation) and their host ( $s_{1}$ foliation). Compiled from Behr (1968) and Eilers et al. (2000). The Meissen Massif intruded a pull-apart structure during ongoing dextral strikeslip tectonics in the Elbe Zone. The insets show recalculated pole figures of $\mathrm{K}$-feldspar and oligoclase from the sample 1 locality in relation to Earth coordinates. Distinct maxima of the (010) faces indicate a strong, sub-horizontal alignment of both feldspars defining the magmatic foliation.

b Simplified geological map of the Meissen Massif showing the brittle structures. Modified after Eilers et al. (2000)
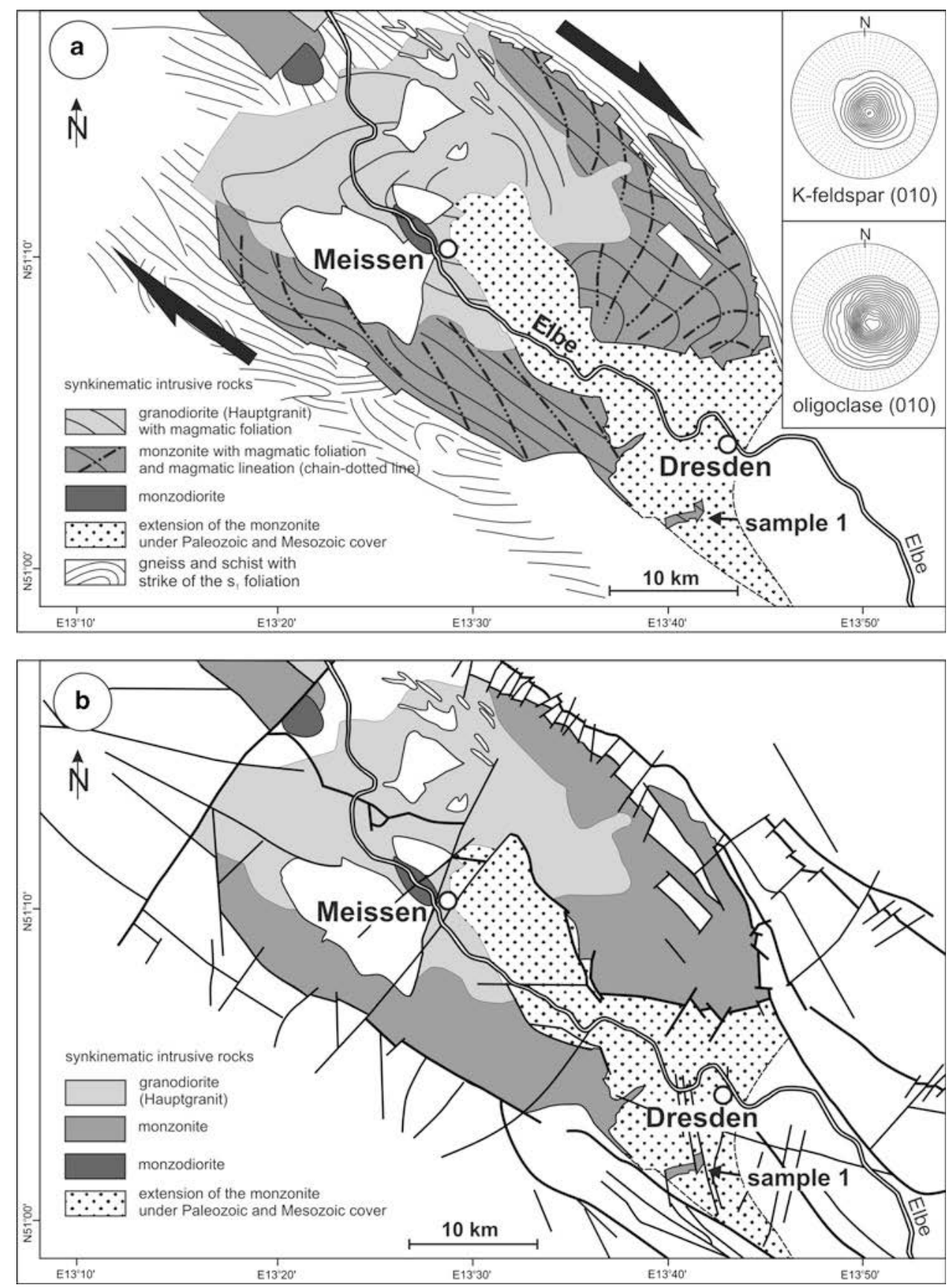

structures of the host rocks. However, in the northern part of the NW-SE-striking pluton the magmatic lineation strikes consistently NW-SE (Behr 1968), which possibly indicates weak syn-intrusive influence of the external stress field. Behr (1968) pointed out that the magmatic lineation is similar for the different intrusion phases of the pluton. The magmatic lineation of the Podlesí dyke granite plunges $4^{\circ}$ northward and corresponds to the regional lineation pattern of the pluton. The strike of the Eibenstock-Nejdek pluton and its magmatic lineation are parallel to the strike of the Gera-Jáchymov-Zone (GJZ; Fig. 9b). The GJZ is a
NW-SE-striking, 7- to 14-km-wide and 250-km-long fault system, which penetrates and borders the eastern part of the Eibenstock-Nejdek pluton. It is predominantly characterised by vertical shear movements (dip-slip) during and after pluton emplacement, extends down to the Moho (e.g. Bankwitz et al. 1993; Behr et al. 1994; Blecha et al. 2009) and is still active (R. Wittenburg, pers. comm.). The Podlesí granite is situated in the centre of the GJZ. The crustal magmas of the Eibenstock-Nejdek pluton and the related Podlesí granite stock presumably utilised the faults of the GJZ for magma ascent (Blecha et al. 2009), 
Fig. 9 a Simplified geological map of the northern part of the Eibenstock-Nejdek pluton showing the deformation fabrics of the post-kinematic intrusive rocks (magmatic foliation and lineation) and their host ( $\mathrm{s}_{1}$ foliation). Compiled from Behr (1968) and Hoth et al. (1995). The insets show recalculated pole figures of albite and quartz of the Podlesí dyke granite in relation to Earth coordinates. The distinct maximum of the albite (010) faces indicates sub-horizontal alignment of the crystals defining the magmatic foliation. The quartz (011) rhombs are partially parallel, partially perpendicular to the horizontal (=foliation) plane. b Simplified geological map of the northern part of the Eibenstock-Nejdek pluton showing the brittle structures. Modified after Hoth et al. (1995)
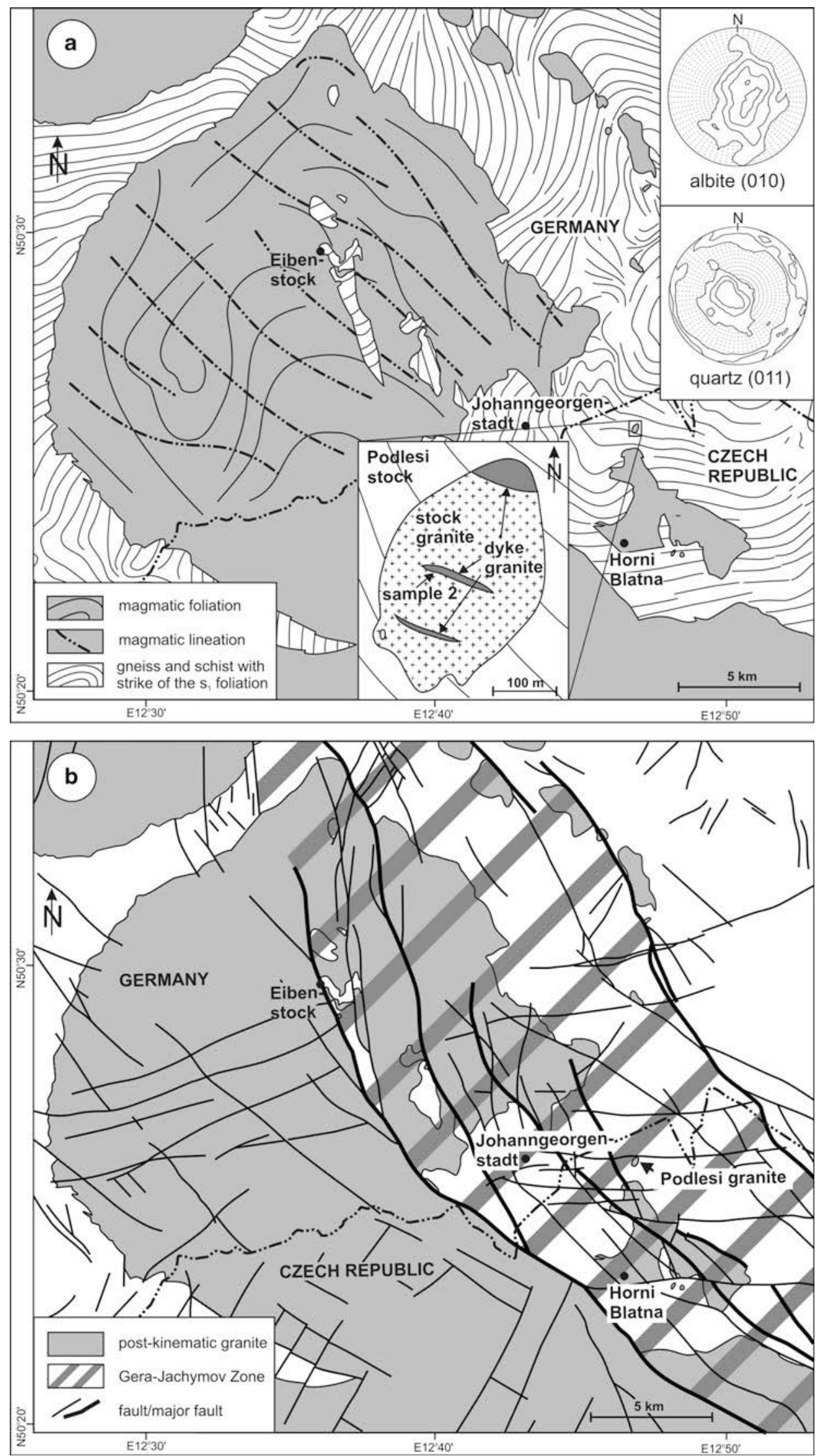
which may explain the parallelism of the pluton axis and GJZ. It is concluded that the emplacement of magmas of the Eibenstock-Nejdek pluton can be interpreted as powerful press-in of crystal-loaded magma into the upper crust. The LPO geometry of the Podlesí quartz indicating flattening strain supports this conclusion.

\section{Conclusions}

In this study, polyphase LPO analysis by means of neutron diffraction was successfully applied to fine- to mediumgrained granitic rocks. The following conclusions regarding the LPO development in the Meissen monzonite and the Podlesí dyke granite can be drawn.

The late-Variscan Meissen monzonite, which syn-kinematically intruded the strike-slip stress field of the Elbe Zone, shows pronounced LPOs of K-feldspar and plagioclase, as well as a weak LPO of amphibole due to alignment of the oblate phenocrysts during magmatic flow. The LPO of amphibole is less pronounced, because the shape anisotropy is not as strong as the shape anisotropy of the feldspars. Quartz shows a weak but distinct LPO characterised by a three-fold maximum distribution, which is symmetrical with respect to the foliation plane/flow plane. The LPO is untypical for a deformational LPO, indicating that solid-state deformation processes leading to recrystallisation and sub-grain formation were too weak to cause significant crystallographic re-orientation of quartz. The most probable interpretation of the uniform great-circle $c$-axis distribution is oriented quartz nucleation and growth under the influence of an anisotropic stress field, whereby the $c$-axes of quartz tend to align sub-parallel to the foliation plane. Epitaxic growth of quartz on aligned feldspar phenocrysts may explain the poorly defined $c$-axis maximum perpendicular to the foliation plane.

The Podlesí dyke granite representing a post-kinematic late-Variscan granite exhibits a pronounced LPO of albite and zinnwaldite, which is characterised by parallelism of the (010) face and the flow plane. The crystal alignment is explained by laminar magmatic flow. K-feldspar shows no LPO at all, because it crystallised as a late phase from the residual melt, as indicated by the P-rich rims (Breiter 2002). The weak quartz LPO of the Podlesí dyke granite is characterised by a small-circle $c$-axis distribution with a large opening angle around the foliation normal. This LPO pattern approximately corresponds to the LPO geometry in the flattening field of the local strain field. Due to the absence of typical deformation features, the quartz LPO is interpreted as the result of magmatic flow. During magmatic flow quartz adhered with the rhombohedral facies to the $(010)$ faces of aligned albite and to the (001) faces of zinnwaldite.
Due to shape anisotropy of the attachments, quartz crystals were passively aligned by magmatic flow.

Magmatic flow is the dominant process causing LPO in the syn-kinematic Meissen monzonite and in the postkinematic Podlesí granite. In the case of the Meissen monzonite, regional strike-slip shearing superimposes the magmatic flow fabric but does not result in a typical deformational LPO. Oriented crystal growth of late minerals during final magma solidification seems to be a significant process contributing to the LPO development, in particular in rocks that are characterised by pronounced flow alignment of non-equidimensional phenocrysts.

The results also show that neutron diffraction is suitable to determine the mineral LPOs on polyphase and coarsegrained rocks. Especially the SKAT neutron diffractometer at Dubna offers the necessary preconditions, above all high resolution and the opportunity to investigate very large sample volumes. Assuming optimal experimental conditions, even distinct LPOs of minor minerals with volume fractions down to $5 \%$ can be quantified.

Acknowledgments We thank P. Bankwitz, R. Boyd and I. Henderson for their critical comments and assistance with the presentation. We appreciated the constructive reviews by Ron Vernon and Scott Paterson, which improved the quality of the manuscript considerably. The study was supported by the Deutsche Forschungsgemeinschaft through grant MU 1717/2-1, the Natural History Museum of London, and the Geological Survey of Norway. Bernd Leiss is grateful for the financial support of the German Federal Ministry of Education and Research (BMBF 03DU0GO1-8).

\section{References}

Akhavan AC (2010) The quartz page. http://www.quartzpage. de/gro_text.html. Accessed 4th July 2010

Arzi AA (1978) Critical phenomena in the rheology of partially melted rocks. Tectonophysics 44:173-184

Bankwitz E, Bankwitz P (1994) Crustal structure of the Erzgebirge. In: Seltmann R, Kämpf H, Möller P (eds) Metallogeny of collisional orogens. Czech Geol, Surv Prague, pp 20-34

Bankwitz P, Betzl M, Drechsler LP, Feldmann K, Fuentes L, Kämpf H, Walther K (1985) Fabric analysis of the quartz component in granulite rocks using neutron Time-of-Flight-Diffraction. Gerlands Beitr Geophysik 94:507-521

Bankwitz P, Gross U, Bankwitz E (1993) Krustendeformation im Bereich der Finne-Kyffhäuser-Gera-Jáchymov-Zone. Z Geol Wiss 21:3-20

Behr HJ (1966) Die Verwendung von Lackfilmen (Ätzbildern) zur Strukturuntersuchung von metamorphen und magmatischen Gesteinen. Monatsber Dt Akad Wiss Berlin 8(12):897-904

Behr HJ (1967) Zur tektonischen Analyse magmatischer Körper unter besonderer Berücksichtigung des Quarzteilgefüges.Teil I: Methodische Grundlagen und die Beziehung des Korngefüges zur Granittektonik. Freiberger Forschungsh C215:9-59

Behr HJ (1968) Zur tektonischen Analyse magmatischer Körper unter besonderer Berücksichtigung des Quarzteilgefüges. Teil II: Ergebnisse komplexer granittektonischer Untersuchungen in der Elbtalzone, der Lausitz und Westsachsens. Freiberger Forschungsh C219:33-98 
Behr HJ, Dürbaum HJ, Bankwitz P (eds) (1994) DEKORP Research Group/B Crustal structure of the Saxothuringian Zone: results of the deep seismic profile MVE-90(East). Z geol Wiss 22:647-769

Beus AA, Severov EA, Sitnin AA, Subbotin KD (1962) Albitized and greisenized granites (apogranites). Nauka, Moscow (in Russian)

Blecha V, Štemprok M, Fischer T (2009) Geological interpretation of gravity profiles through the Karlovy Vary granite massif (Czech Republic). Studia Geophysica Geodætica 53:295-314

Blumenfeld P, Bouchez JL (1988) Shear criteria in granite and migmatite deformed in the magmatic and solid states. J Struct Geol 10:361-372

Bouchez JL (1997) Granite is never isotropic: an introduction to AMS studies of granitic rocks. In: Bouchez JL, Hutton DWH, Stephens WE (eds) Granite: from segregation of melt to emplacement fabrics. Kluwer, Dordrecht, pp 95-112

Breiter K (2001) Phosphorus- and fluorine-rich granite system at Podlesí. In: Breiter K (ed) Phosphorus- and Fluorine-rich Granites. Abstracts-Excursion guide-Program. International Workshop Podlesí, October 16-19 2001, Czech Geol Surv, Prague, pp 54-78

Breiter K (2002) From explosive breccia to unidirectional solidification textures: magmatic evolution of a phosphorus- and fluorinerich granite system (Podlesí Krušné hory Mts., Czech Republic). Bull Czech Geol Surv 77:67-92

Breiter K, Frýda J, Seltmann R, Thomas R (1997) Mineralogical evidence for two magmatic stages in the evolution of an extremely fractionated P-rich rare-metal granite: the Podlesí Stock, Krušné Hory, Czech Republic. J Petrol 38:1723-1739

Breiter K, Müller A, Leichmann J, Gabašová A (2005) Textural and chemical evolution of a fractionated granitic system: the Podlesí stock, Czech Republic. Lithos 80:323-345

Chlupáčová M, Breiter K (1998) Physical properties of extremely fractionated P-rich rare-metal granite: borehole PTP-1, the Podlesí stock, Krušné Hory Mts., Czech Republic. Acta Univ Carol Geol 42:28-31

Damm V, Feldmann K, Frischbutter A, Kleinsteuber W, Walther K (1990) The structural evolution of an orthogenesis-fold within the Reitzenhainer Rotgneisstruktur (Erzgebirge Mts., Germany). Textures Microstruct 12:15-35

Davidson JP, Font L, Charlier BLA, Tepley FJ III (2008) Mineralscale $\mathrm{Sr}$ isotope variation in plutonic rocks-a tool for unravelling the evolution of magma systems. EEST Royal Soc Edinburgh 97:357-367. doi:10.1017/S0263593300001504

Dingwell DB (1987) Melt viscosities in the system $\mathrm{NaAlSi}_{3} \mathrm{O}_{8}-\mathrm{H}_{2} \mathrm{O}-$ $\mathrm{F}_{2} \mathrm{O}_{-1}$. In: Mysen BO (ed) Magmatic processes: physicochemical principles. Geochem Soc Spec Publ 1:423-433

Drake TG (1990) Structural features in granular flows. J Geophys Res 95:8681-8696

Eilers H, Engelhardt-Sobe A, Jaranowska B, Brzezkiewicz G, Tomas $\mathrm{R}$ (eds) (2000) Geological map Lausitz-Jizera-Karkonosze (without Cenozoic sediments) 1: 100000. Sächsisches Landesamt für Umwelt und Geologie, Freiberg

Fenn PM (1986) On the origin of graphic granite. Amer Miner 71:325-330

Gapais D, Barbarin B (1986) Quartz fabric transition in a cooling syntectonic granite (Hermitage Massif, France). Tectonophysics 125:357-370

Helming K (1992) Minimal pole figure ranges for quantitative texture analysis. Textures Microstruct 19:45-54

Helming K, Eschner T (1990) A new approach to texture analysis of multiphase materials using a texture component model. Cryst Res Technol 25:K203-K208

Hobbs BE, Means WD, Williams PF (1976) An outline of structural geology. Wiley, New York

Hofmann M, Linnemann U, Gerdes A, Ullrich B, Schauer M (2009) Timing of dextral strike-slip processes and basement exhumation in the Elbe Zone (Saxo-Thuringian Zone): the final pulse of the Variscan orogeny in the Bohemian Massif constrained by LASF-ICP-MS U-Pb zircon data. Geol Soc London Spec Publ 327:197-214

Hoth J, Tischendorf G, Berger H-J (eds) (1995) Geologische Karte Erzgebirge/Vogtland. 1:100000. Sächsisches Landesamt für Umwelt und Geologie, Freiberg

Kamb WB (1959) Theory of preferred crystal orientation developed by crystallization under stress. J Geol 67:158-170

Kirwin DJ (2005) Unidirectional solidification textures associated with intrusion-related Mongolian mineral deposits. In: Seltmann R, Gerel O, Kirwin DJ (eds) Geodynamics and metallogeny of Mongolia with a special emphasis on copper and gold deposits. IAGOD Guidebook Series 11: CERCAMS/NHM London, pp 63-84

Kroner U, Hahn T, Romer RL, Linnemann U (2007) The Variscan orogeny in the Saxo-Thuringian zone-heterogeneous overprint of Cadomian/Palaeozoic peri-Gondwana crust. In: Linnemann U, Nance RD, Kraft P, Zulauf G (eds) The evolution of the Rheic Ocean: From Avalonian-Cadomian active margin to Alleghenian-Variscan collision. Boulder, Colorado, Geol Soc Am Spec Paper 423:153-172

Leiss B, Molli G (2003) "High-Temperature" texture in naturally deformed Calcite marble from the Alpi Apuane, Italy. J Struct Geol 25:649-658

Leiss B, Gröger HR, Ullemeyer K, Lebit H (2002) Textures and microstructures of naturally deformed amphibolites from the northern Cascades, NW USA. In: De Meer S, Drury MR, De Bresser JHP, Pennock GM (eds) Deformation mechanisms, rheology and tectonics: current status and future perspectives. Geol Soc London, Spec Publ 200:219-238

Linnemann U, Schauer M (1999) Die Entstehung der Elbezone vor dem Hintergrund der cadomischen und variszischen Geschichte des Saxothuringischen Terranes-Konsequenzen aus einer abgedeckten geologischen Karte. Z Geol Wiss 27:529-561

Maros G, Palotás K, Koroknai B, Sallay E (2002) Tectonic evaluation of borehole PTP-3 in the Krušne hory Mts with ImaGeo mobile corescanner. Bull Czech Geol Surv 77:105-112

Maroscheck EF (1933) Beiträge zur Kenntnis des Granites von Mauthausen in Oberösterreich. Min Petr Mitt 43:375-405

Mattern F (1996) The Elbe zone at Dresden-a Late Paleozoic pullapart intruded shear zone. Z Dt Geol Ges 147:57-80

Matthies S, Vinel GW (1982) On the reproduction of the orientation distribution function of texturized samples from reduced pole figures using the conception of a conditional ghost correction. Physica Status Solidi B112:111-120

Matthies S, Wenk HR, Vinel GW (1988) Some basic concepts of texture analysis and comparison of three methods to calculate orientation distributions from pole figures. J Appl Cryst 21:285-304

Mierzejewski M (1968) Tektonische Untersuchungen im KarkonoszeGranite (Riesengebirge). Freiberger Forschungsh C 219:99-107

Müller A, Seltmann R (1999) The genetic significance of snowball quartz in high fractionated tin granites of the Krušne hory/ Erzgebirge. In: Stanley CJ et al (eds) Mineral deposits: processes to processing, vol 1. Balkema, Rotterdam, pp 409-412

Müller A, Kronz A, Breiter K (2002) Trace elements and growth patterns in quartz: a fingerprint of the evolution of the subvolcanic Podlesí Granite System (Krušne Hory, Czech Republic). Bull Czech Geol Surv 77(2):135-145

Müller A, Behr H-J, van den Kerkhof AM, Kronz A, Koch-Müller M (2009) The evolution of late-Hercynian granites and rhyolites documented by quartz-a review. Earth Environ Sci Trans R Soc Edinburgh 100:185-204

Nasdala L, Wenzel T, Pidgeon RT, Kronz A (1999) Internal structures and dating of complex zircons from Meissen Massif monzonites, Saxony. Chem Geol 156:331-341 
Passchier CW, Trouw RAJ (2006) Microtectonics. Springer, Berlin

Paterson SR, Vernon RH, Tobisch OT (1989) A review of criteria for the identification of magmatic and tectonic foliations in granitoids. J Struct Geol 11:349-363

Paterson SR, Fowler TK, Schmidt KL, Yoshinobu AS, Yuan ES, Miller RB (1998) Interpreting magmatic fabric patterns in plutons. Lithos 44:53-82

Pfeiffer L (1964) Beiträge zur Petrologie des Meißener Massivs. Freiberger Forschungsh C179:1-222

Phillips WJ (1965) The deformation of quartz in granite. Geol J $4: 391-414$

Pietzsch K (1927) Der Bau des erzgebirgisch-lausitzer Grenzgebietes. Abh Sächs Geol Landesanstalt 2:1-28

Rauche E (1991) Spätvariszische Kompressionstektonik am Südwestrand der Elbezone. Z Geol Wiss 19:463-475

Romer RL, Linnemann U, Gehmlich M (2003) Geochronologische und isotopengeochemische Randbedingungen für die cadomische und variszische Orogenese im Saxothuringikum. In: Linnemann U (ed) Das Saxothuringikum. Geologica Saxonia 48/49:111-120

Sander B (1929) Zur tektonischen Analyse von Schmelztektoniten. Sitzungsber Heidelberger Akad Wiss, Math-Nat Kl, 13. Abh De Gruyter, Berlin

Schmid SM, Casey M (1986) Complete fabric analysis of some commonly observed quartz $c$-axis pattern. Geophys Monogr $36: 263-285$

Schulmann K, Jezek J, Venera Z (1997) Perpendicular linear fabrics in granite: markers of combined simple shear and pure shear flows? In: Bouchez JL, Hutton DWH, Stephens WE (eds) Granite: from segregation of melt to emplacement fabrics. Kluwer, Dordrecht, pp 159-176

Sen K, Mamtani MA (2006) Magnetic fabric, shape preferred orientation and regional strain in granitic rocks. J Struct Geol 28:1870-1882. doi:10.1016/j.jsg.2006.07.005

Shannon JR, Walker BM, Carten RB, Geraghty EP (1982) Unidirectional solidification textures and their significance in determining relative ages of intrusions at the Hederson Mine, Colorado. Geology 10:293-297

Sharp WD, Wenzel T, Nasdala L, Mertz DF, Becker T (1997) Geochronology of Hercynian Meissen Massif magmatic rocks based on ${ }^{40} \mathrm{Ar} /{ }^{39} \mathrm{Ar}$ (amphibole, mica) and ${ }^{206} \mathrm{~Pb} /{ }^{238} \mathrm{U}$ SHRIMP (zircon) data. Schriftenreihe Dt Geol Ges 2:108-109
Shelley D (1993) Igneous and metamorphic rocks under the microscope: classification, textures, microstructures, and mineral preferred orientations. Chapman and Hall, London

Stel H (1992) Diagnostic microstructures for primary and deformational quartz rods in graphic granite. Amer Miner 77:329-335

Stel H, Breedveld M (1990) Crystallographic orientation patterns of myrmekitic quartz: a fabric memory in quartz ribbon-bearing gneisses. J Struct Geol 12:19-28

Táborská Š, Breiter K (1998) Magnetic anisotropy of an extremely fractionated granite: the Podlesí stock, Krušné hory Mts., Czech Republic. Acta Univ Carol Geol 42:147-149

Thomas R, Rhede D, Trumbull RB (1996) Microthermometry of volatile-rich silicate melt inclusions in granitic rocks. Z Geol Wiss 24:505-526

Ullemeyer K, Spalthoff P, Heinitz J, Isakov NN, Nikitin AN, Weber K (1998) The SKAT texture diffractometer at the pulsed reactor IBR-2 at Dubna: experimental layout and first measurements. Nucl Instr Meth Phys Res A 412(1):80-88

Van der Molen I, Paterson MS (1979) Experimental deformation of partially-melted granite. Contrib Miner Petrol 70:299-318

Vernon RH (1976) Metamorphic processes. Murby, London

Vernon RH (2000) Review of microstructural evidence of magmatic and solid-state flow. Electron Geosci 5(2):1-23

Vigneresse JL, Barbey P, Cuney M (1996) Rheological transitions during partial melting and crystallization with application to felsic magma segregation and transfer. J Petrol 57:1579-1600

Watznauer A, Behr HJ (1966) Quarzregelung in magmatischen Gesteinen. Tschermaks Miner Petrogr Mitt 11(3-4):290-303

Wenzel T, Mercolli I, Oberhänsli R (1991) The plutonic rocks of the Meissen Massif (Germany): evidence for open and closed system fractionation processes. Schweiz Miner Petrogr Mitt 71:371-390

Wenzel T, Mertz DF, Oberhänsli R, Becker T, Renne PR (1997) Age, geodynamic setting, and mantle enrichment processes of a K-rich intrusion from the Meissen Massif (Northern Bohemian Massif) and implications for related occurrences from the MidEuropean Hercynian. Geol Rundsch 86:556-570

Yoder HR (1950) High-low quartz inversion up to 10, 000 bars. Trans Am Geophys Union 31:827-835

Žák J, Verner K, Týcová P (2008) Multiple magmatic fabrics in plutons: an overlooked tool for exploring interactions between magmatic processes and regional deformation? Geol Mag 145:537-551. doi:10.1017/S0016756808004573 